\title{
When More Than Money Talks: Multi-Criteria Decision Analysis of Fuel Cells for Sustainable Power Supply in Sub-Saharan Minigrids
}

\author{
Nikolas Schöne ${ }^{1^{*}}$, François de Rochette ${ }^{1}$, Boris Heinz $z^{1,2}$ \\ *Corresponding author
}

\author{
1 Department of Energy Systems, Technische Universität Berlin, Einsteinufer 25, 10587 Berlin \\ e-mail: n.schoene@tu-berlin.de \\ T: +49-(0)30-314-28634 \\ e-mail: b.heinz@tu-berlin.de \\ 2 Hudara gGmbH, Rollbergstr. 26, 12053 Berlin \\ e-mail: bheinz@hudara.org
}

\begin{abstract}
Strategies of countries in Sub-Saharan Africa include minigrid deployment in order to progress towards providing access to electricity to the currently 500 million people living without access in rural areas by today. While recent studies on fuel cells in such minigrid energy systems are limited to technical and economic considerations, this paper performs a multi-criteria decision analysis to compare their fit into the economic, technical, environmental, and social system against established fossil and renewable power generation technologies.

Findings from scenarios which shed light on 1. strategically important criteria according to academic expert opinions captured in a survey, 2. decisive criteria for actual market penetration of power generation technologies in the respective setting and 3. future parameter and criteria in alliance with sustainable development, indicate the fuel cell to be highly suitable for rural power generation in minigrids. The major disadvantage of low economic performance of decentralized hydrogen production and usage by fuel cells in minigrids could be overcome by large-scale centralized water electrolysis. But as reliability of supply and synergies to other end-uses are promising, the authors suggest to direct future work to define economic niches and use-cases for decentralized hydrogen production in minigrids.
\end{abstract}

Index terms: Access-to-energy, sustainable electrification, fuel cell, hydrogen, multi-criteria decision analysis, rural minigrid, technology evaluation criteria, expert survey.

\section{INTRODUCTION}

As electricity is proven to be a fundamental pillar of human development as a collective term for economic [1], cultural and social development [2], efforts in sustainable electrification have gained increasing momentum in the past decade [3]. However, nine years before completion of the Sustainable Development Goal(SDG) period, the target of universal electrification is in great distance with still 600 million people having no access to electricity in Sub-Saharan Africa (SSA) only [3]. Especially and unproportionally affected is the rural population where only three out of ten people had reliable access to electricity in 2018 [4]. Strategies and blueprints of countries facing forced action to progress towards rural electrification rely on combined approaches of grid extension, deployment of Solar Home Systems and isolated minigrids. Filling the niche in between the two aforementioned extrema, minigrids combine acceptable deployment complexity and comparatively low costs with a high Tier-level of supply [5]. With this, minigrids are considered to be the most suitable electrification pathway for more than a half of the population currently living without access to electricity (52.5\%) [6].
As the common range of demand in such minigrids allows for a variety of power generation technologies to be integrated, fuel cells, converting hydrogen into electricity, have increasingly gained attention in the recent past [7]. Besides its use for power production, hydrogen can in addition be utilized as clean cooking fuel [8], as a motive fuel for mobility [9] or as a base substance in agricultural fertilizer [10], making hydrogen an all-round talent in the field of isolated minigrids.

However, whilst research on the application of hydrogen technologies in isolated Global North settings are abundant - with common objects of investigation being single houses [11-17], small island or remote villages [18, 19], industrial applications [20] or stand-alone systems which require uninterruptible power supply [21-24] - considerations for Global South minigrids still remain limited, both in number and scope. Most studies apply modeling tools to assess the techno-economic potential of fuel cells in minigrid energy systems [25-29]. A very comprehensive technical review on their integration in microgrids is provided by Akinyele et al. [7]. Documentation of demonstration projects, such as the "Sunfold" (Tiger Power) product deployment, combining a reversible 
fuel cell system, solar photovoltaic (PV) and battery storage in a container solution in Uganda minigrids [30], is limited to technical description, or economic considerations in other cases [31]. Just recently (March 2021), SFC Energy has announced to deploy 48 fuel cells of 500W each in rural northern India to electrify isolated communities [32].

With increasing knowledge about interlinkages between SDG 7 and other dimensions of development [33] the belief grows that power generation technologies must not only be evaluated by their technical capabilities or economic performance but rather their holistic fit into the economic, technical, environmental and social system [34]. History of technology development has shown technical frontrunners to fail in long-lasting energy supply, as the technologies have not been accepted by the users, ending up abandoned. Likewise, energy technologies harming the environment are continuously losing market share, as recent policies and regulations penalize such operations in the long-term.

In order to capture the holistic potential of fuel cells for sustainable power supply in rural minigrids and evaluate their competitiveness against established fossil and renewable technologies, this paper performs a multi-criteria decision analysis (MCDA) on seven power generation technologies, and opens the discussion to include technical, environmental, economic and social criteria to compare the technologies. Introducing scenarios to include expert opinions, characteristics currently decisive for market success and potential future developments, the analysis additionally sheds light on strategically important and future perspective technology parameter.

Following the sequence of a MCDA method, illustrated in Figure 1, the material and methods section first defines system boundaries and technologies. Subsequently, subsection Criteria selection presents the methods used to define a compact set of relevant evaluation criteria, combining thorough literature review with statistical analysis. The Scenario development section develops three scenarios to introduce subjective weights to the defined evaluation criteria, including weights according to an academic expert survey, criteria decisive for current market shares of established power generation technologies and future development of technologies and political ambition. The Results briefly present strengths and weaknesses of the fuel cell technology before highlighting a ranking of the compared technologies. Main findings are taken up by the Discussion, which is additionally fed with statements of an expert survey. The researchers conclude with a summary of findings and suggestions for future work.

\section{MATERIAL AND METHODS}

\section{A. Technology Selection and System Boundaries}

The following section introduces the scope of technologies considered in the MCDA and their main characteristics. Special attention is paid to the fuel cell and considered system boundaries.

- As the definition of a minigrid is broad in scope, with only the characteristic of being founded on a decentralized form of energy generation that relies on local infrastructures for generation and distribution [38-40] to be consistent in available descriptions, criteria must be defined to limit the scope of technologies included in the analysis. In the present paper, the following restrictions have been made.

- As 'generation' is by far the core functionality of minigrids [39] being most prominent discussion to minigrid developer and users, the analysis only considers power generation technologies. This excludes any 'conversion', 'consumption', 'control, manage and measure' and 'storage' devices.

- As the paper considers technologies rather than energy systems, hybrid systems or any (partly) interaction with a connected grid are excluded.

- To fit in the common approach of defining minigrids by the total installed generation capacity, with common thresholds being $100 \mathrm{~kW}$ [40], $1 \mathrm{MW}$ [41], or even $10 \mathrm{~kW}-10 \mathrm{MW}[38,42]$, technologies considered in the analysis must be scalable in a range between 10 $\mathrm{kW}$ and $1 \mathrm{MW}$.

- Technologies considered must not be restricted to extremely specific environmental conditions, but must be applicable across a broad spectrum on the SSA mainland, excluding e.g. tidal current power generation.

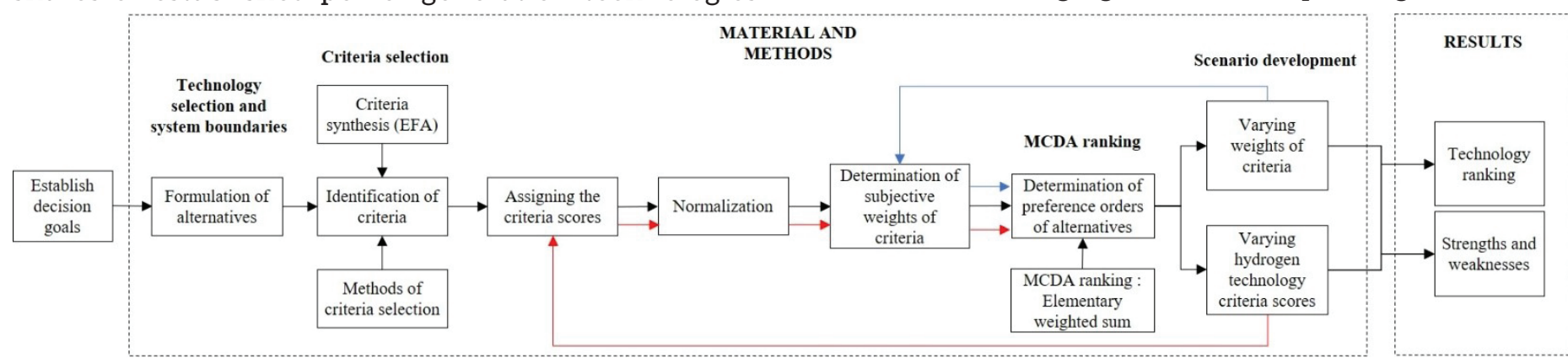

Fig. 1. Simplified and adjusted MCDA process in sustainable decision making [35-37]. 
- Technologies considered must not only be proposed in literature or research, but evidence on recent operation in a SSA minigrid must be present, excluding e.g. geothermal and concentrated solar power generation.

Applying these criteria reduced an initial set of power generation technologies proposed for autonomous minigrids by the World Bank [43] to seven unit types, including the biogas power system, diesel generator, micro-hydropower, micro-gasturbine, microwindturbine, solar photovoltaic (PV) and the fuel cell. An issue of discussion regarding fuel cell systems is whether to utilize on-site or off-site generated hydrogen. Therefore, the paper distinguishes between both possibilities. While the usage of offsite produced hydrogen meets the above listed criteria, the conversion of on-site produced hydrogen requires to consider additional technologies for primary electricity generation and its conversion into hydrogen at first, which this paper on exemption allows to be included in the analysis.
Figure 2 therefore differentiates between the distinct options of hydrogen integration with ascending level of self-sufficiency, being a) off-site production of hydrogen, and b) on-site production of hydrogen and utilization by a (regenerative) fuel cell. As indicated by the dashed lines, the system boundaries for the on-site case b) includes any primary electricity generation technology, notably effecting the results in later stage. As such upstream technology the best performing renewable technology is considered in each respective evaluation criteria later.

Although Figure 2 proposes a separated electrolyzer and fuel cell for the on-site production and utilization of hydrogen, the two systems may be integrated and operated in dual mode, called a regenerative fuel cell, that is they may be operated as an electrolyzer and alternately as fuel cell [7]. For a more detailed technical description of the integration of hydrogen in isolated minigrids the researchers refer to Akinyele et al. [7], while Buttler and Spliethoff provide a recent and comprehensive study on technical and economic key characteristics of hydrogen systems [44].

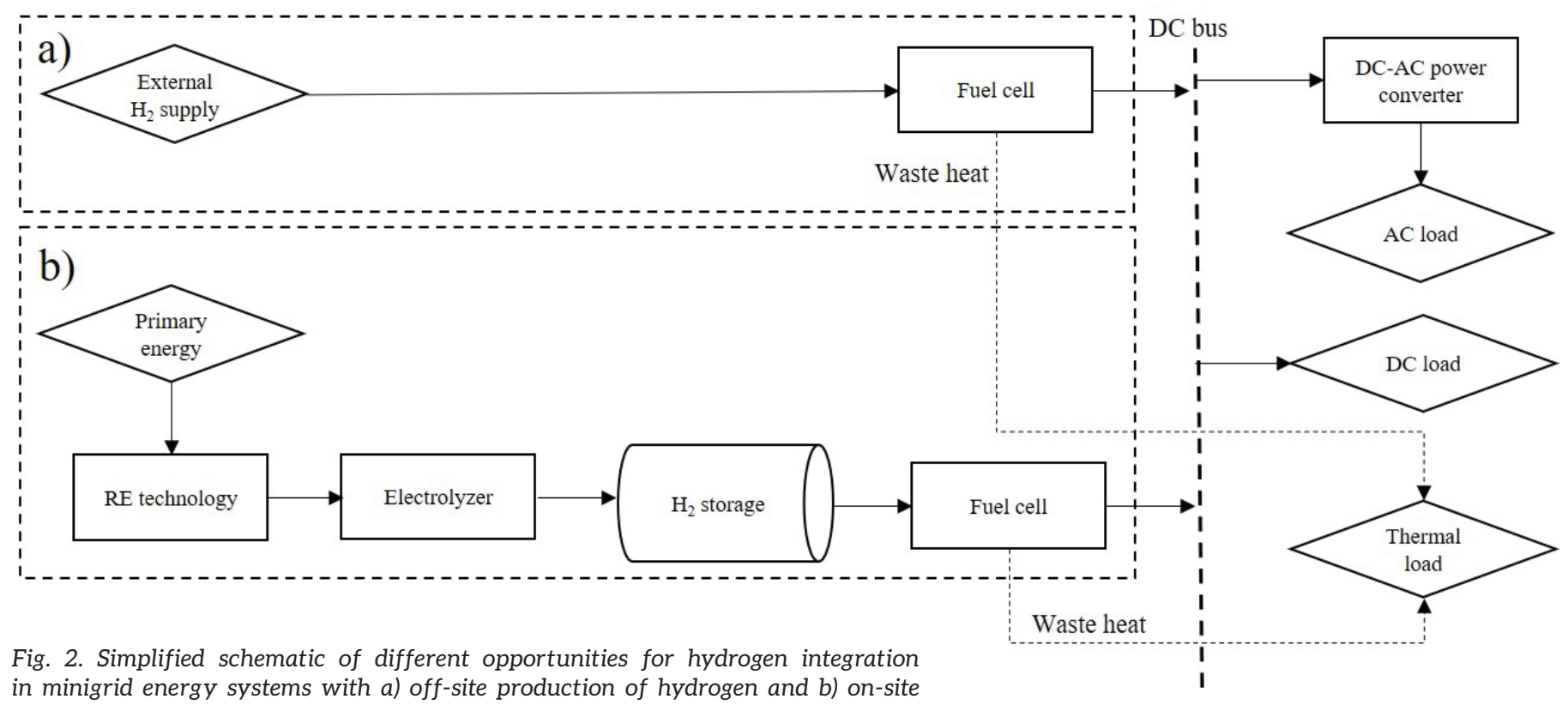

in minigrid energy systems with a) off-site production of hydrogen and b) on-site production and utilization of hydrogen.

As the technologies considered in the MCDA might vary in their individual technical construction and therefore characteristics, the analysis generalizes such differences in construction to include evidence from different literatures according to the description of technologies contained within Table 1. 


\section{TABLE I \\ MAIN CHARACTERISTICS OF ASSESSED POWER GENERATION \\ TECHNOLOGIES [38, 39, 41, 43, 45-47].}

\begin{tabular}{|c|c|c|}
\hline Technology label & Technology characteristics & Current use \\
\hline $\begin{array}{l}\text { Biogas Power } \\
\text { System }\end{array}$ & $\begin{array}{l}\text { - Solid biomass feedstock (considered renewable) converted by means of } \\
\text { an anaerobic gasifier to produce biogas for combustion with power } \\
\text { production unit. } \\
\text { - Biomass slurry remains as side-product. } \\
\text { - Typical unit capacity: } 10 \mathrm{~kW}-1 \mathrm{MW}\end{array}$ & $\begin{array}{l}\text { Biogas is predominantly } \\
\text { used as cooking fuel but } \\
\text { also for electrification } \\
\text { purposes. }\end{array}$ \\
\hline Diesel generator & $\begin{array}{l}\text { - Stationary diesel fueled internal combustion engine, excluding diesel } \\
\text { storage. } \\
\text { - Typical unit capacity: } 1 \mathrm{~kW}-1 \mathrm{MW}\end{array}$ & $\begin{array}{l}\text { Currently the most used } \\
\text { technology for rural } \\
\text { electrification in SSA. }\end{array}$ \\
\hline $\begin{array}{l}\text { Pico-/Micro- } \\
\text { hydropower }\end{array}$ & $\begin{array}{l}\text { - Run-of-river or tributary pico- and micro hydropower units. } \\
\text { - Typical unit capacity: } 1 \mathrm{~kW}-1 \mathrm{MW}\end{array}$ & $\begin{array}{l}\text { Mature technology } \\
\text { often used in South-East } \\
\text { Asia, emerging in SSA. }\end{array}$ \\
\hline Micro-gas turbine & $\begin{array}{l}\text { - Small scale turbine engine that runs on natural gas. } \\
\text { - Typical unit capacity: } 30 \mathrm{~kW}-200 \mathrm{~kW}\end{array}$ & $\begin{array}{l}\text { Widely used technology } \\
\text { for rural electrification } \\
\text { in SSA. }\end{array}$ \\
\hline $\begin{array}{l}\text { Micro-wind } \\
\text { turbine }\end{array}$ & $\begin{array}{l}\text { - Onshore horizontal axis turbines with varied generator type. } \\
\text { - Typical unit capacity: } 1 \mathrm{~kW}-1 \mathrm{MW}\end{array}$ & $\begin{array}{l}\text { Widely used technology } \\
\text { for rural electrification } \\
\text { in SSA. }\end{array}$ \\
\hline PV & $\begin{array}{l}\text { - Residential, commercial or industrial installations of photovoltaic solar } \\
\text { panels, including power controlling devices. Generally, our data } \\
\text { sources do not specifically distinguish among the different panel } \\
\text { manufacturing technologies. } \\
\text { - Ground mounted system considered. } \\
\text { - Typical unit capacity: } 1 \mathrm{~kW}-1 \mathrm{MW}\end{array}$ & $\begin{array}{l}\text { Widely used for stand- } \\
\text { alone systems (Solar } \\
\text { Home Systems) as well } \\
\text { as in minigrids. }\end{array}$ \\
\hline a) Fuel cell & $\begin{array}{l}\text { - PEM or AEL/AFC and fuel cell of no specific type that runs on off-site } \\
\text { produced hydrogen, assumed to be generated by natural gas reforming. } \\
\text { - Typical unit capacity: } 10 \mathrm{~kW}-1 \mathrm{MW}\end{array}$ & $\begin{array}{l}\text { Pilot tests for } \\
\text { electrification. }\end{array}$ \\
\hline $\begin{array}{l}\text { b) Regenerative } \\
\text { Fuel cell }\end{array}$ & $\begin{array}{l}\text { - PEM or AEL/AFC electrolyzer and fuel cell of no specific type that } \\
\text { runs on on-site produced hydrogen, including any upstream renewable } \\
\text { power generation technology to be assumed the best performing } \\
\text { technology of each evaluation criteria. } \\
\text { - Typical unit capacity: } 10 \mathrm{~kW}-1 \mathrm{MW}\end{array}$ & $\begin{array}{l}\text { Pilot tests for } \\
\text { electrification and as } \\
\text { clean cooking fuel. }\end{array}$ \\
\hline
\end{tabular}




\section{B. Criteria Selection}

As the definition of criteria for decision making in technology evaluation is highly complex and requires both theoretical background as well as practical expertise, a mixed method approach was applied, combining thorough literature study and statistical analysis.

The literature research focused on previous studies which defined criteria to evaluate performance of power generation technologies rather than specific energy systems (e.g. indicators such as "the share of renewable energy sources in electricity consumption" are excluded). This literature review revealed a wide set of evaluation criteria amongst a common classification adopted in this paper. Based on the various dimensions of sustainability that a technology might impact on when integrated in a specific context, criteria are categorized in the environmental dimension, technical dimension, economic dimension, and social dimension.

To further synthetize the first exhaustive set of criteria, the five guiding principles for criteria selection proposed by Wang et al. [35] - being the transparency principle, the consistency principle, independency principle, measurability principle and comparability principle - and later used by Maxim for similar purpose as in this paper [34] were consulted. Whilst consistency (consistent method through all alternatives), transparency (transparent definition) and measurability (method and data availability) of criteria must be evaluated for each criterion separately, the independency and comparability principles are character of the whole set of criteria and require statistical processing on homogenized data of the set. Data were obtained in challenging literature research, as most of the sources consulted characterized either only some of the selected technologies or used methodologies that did not fully meet the requirements of this research.

Therefore, results of several studies must be combined to expand the results of others using the original methodology or even to adapt some research methodologies to fit the aims of the current paper. For those cases of missing or inaccurate data qualitative scales and assumptions were introduced.

The independency principle avoids any overlapping of the criteria within the set [35]. Such overlapping would lead to the same aspect being counted multiple times in the final assessment and therefore distort the overall result. It is crucial to detect communalities of the definition of criteria, which, at a certain extend of communality could be combined accordingly. For example, the capital costs of a technology and the levelized costs of electricity (LCOE) produced by the respective technology are logically intertwined. In such case, the more comprehensive criteria of LCOE is seen more suitable for technology comparison. As such communalities in definition often end up in high correlation - either positive or negative for vice versa formulated criteria - statistical analysis assists in the detection of less obvious correlations than the above given example. As only monotonic relationship of two variables $\boldsymbol{x}$ and $\boldsymbol{y}$ (criteria value), and nonlinear correlations within, can be assumed for the data sets introduced in this analysis, Spearman's rank coefficient $\boldsymbol{r}_{\boldsymbol{s}, \boldsymbol{x} \boldsymbol{y}}$ [33] was calculated according to equation 1 ,

$$
r_{s, x y}=1-\frac{6 \sum_{i=1}^{n}\left(x_{i}-y_{i}\right)^{2}}{n\left(n^{2}-1\right)}
$$

where $\boldsymbol{n}$ is the sample size, and $\boldsymbol{x}_{\boldsymbol{i}}$ and $\boldsymbol{y}_{\boldsymbol{i}}$ are individual sample points. Thresholds for indicating a significant correlation are chosen to be 0.6 and -0.6 , respectively [33]. For such criteria that indicated correlation above the respective thresholds, rationale, definition, and methodology were deeply investigated with the intention to uncover whether the correlation might be due to causal relations or simple historic development or even coincidence. If the assumption of causal relation was confirmed, the fewer comprehensive criteria were excluded, otherwise both criteria were retained. Appendix A includes tables for Spearman's rank coefficient and excluded criteria within each dimension of criteria.

The reduced set of evaluation criteria was further treated to test for sufficient discrimination within criteria scores enabling for differentiation of the technologies, as defined in the comparability principle [35]. Such criteria that do not vary significantly along all possible technologies but achieve approximately equal scores can be excluded from the analysis to simplify the process, as they do not impact the overall result. Therefore, coefficient of variance $\boldsymbol{C}_{\boldsymbol{v}}$ was calculated on absolute scales of each criterion $\boldsymbol{i}$ by dividing standard deviation $\boldsymbol{\sigma}_{\boldsymbol{i}}$ by the mean of that criteria $\boldsymbol{\eta}_{\boldsymbol{i}}$

$$
c_{v, i}=\frac{\sigma_{i}}{\eta_{i}}
$$

which gives a relative equivalence among the data. Technology lifetime appears to be the criterion with most equal scores amongst the technologies, resulting in a coefficient of variance of 0.31 . However, this is still considered to deviate enough to include the lifetime criterion for the evaluation. 
TABLE II

FINAL SET OF CRITERIA USED FOR TECHNOLOGY EVALUATION

\begin{tabular}{|c|c|c|c|c|}
\hline Dimension & Criteria & Abbreviation & Definition & Value of measure \\
\hline \multirow[t]{7}{*}{ Technical } & Electrical efficiency & Eff & $\begin{array}{l}\text { Ratio between output electricity and input } \\
\text { energy. }\end{array}$ & $\%$ \\
\hline & Ability to respond to demand & AtD & $\begin{array}{l}\text { Ability to respond to peak demand and ensure } \\
\text { overall grid stability in the long term. }\end{array}$ & $\begin{array}{l}\text { Ranking } \\
1=\text { no } \\
2=\text { slow } \\
3=\text { fast }\end{array}$ \\
\hline & $\begin{array}{l}\text { Ability to provide multiple } \\
\text { end-use services }\end{array}$ & AtSE & $\begin{array}{l}\text { Compatibility of the technology with different } \\
\text { end uses/applications (heating, side products } \\
\text { etc.). }\end{array}$ & $\begin{array}{l}\text { Ranking } \\
1=\text { none } \\
2=\text { waste heat } \\
3=\text { additional products }\end{array}$ \\
\hline & Resource availability & RA & $\begin{array}{l}\text { Direct availability of the primary energy } \\
\text { resource. }\end{array}$ & $\begin{array}{l}\text { Ranking } \\
1=\text { limited resource } \\
2=\text { resource available } \\
3=\text { good potential } \\
4=\text { very good potential } \\
5=\text { independent from } \\
\text { location }\end{array}$ \\
\hline & Maturity & Mat & $\begin{array}{l}\text { Stage of technology development and } \\
\text { dissemination. }\end{array}$ & $\begin{array}{l}\text { Ranking } \\
1=\text { laboratory } \\
2=\text { experimental/pilot } \\
3=\text { confirmed } \\
4=\text { consolidated }\end{array}$ \\
\hline & Capacity factor & $\mathrm{CF}$ & $\begin{array}{l}\text { Ratio of energy produced over a period of time } \\
\text { to maximum theoretical energy that could have } \\
\text { been produced when operated at full capacity } \\
\text { (Load following mode is considered). }\end{array}$ & $\%$ \\
\hline & Lifetime & Lt & $\begin{array}{l}\text { Life expectancy of the separate technology } \\
\text { components before significant interventions are } \\
\text { required. }\end{array}$ & $\mathrm{y}$ \\
\hline Economic & Levelized costs of Electricity & LCOE & $\begin{array}{l}\text { Cost of electricity production over the entire } \\
\text { lifecycle of the technology. }\end{array}$ & $\$ / \mathrm{kWh}$ \\
\hline \multirow{4}{*}{$\begin{array}{l}\text { Environme } \\
\text { ntal }\end{array}$} & Life cycle GHG emission & LC-GHG & GHG emissions over technology life cycle. & $\mathrm{gCO}_{2, \text { eq }} / \mathrm{kWh}$ \\
\hline & Impact on water resources & WR & $\begin{array}{l}\text { Water consumption/withdrawal over the life } \\
\text { cycle of the technology. }\end{array}$ & 1/MWh \\
\hline & Land use & LU & $\begin{array}{l}\text { Land area modified during the lifecycle of the } \\
\text { technology. }\end{array}$ & $\mathrm{m}^{2} / \mathrm{MWh}$ \\
\hline & Noise and visual pollution & NV & $\begin{array}{l}\text { Noise pollution emitted when operating the } \\
\text { technology and visual effects disturbing } \\
\text { population. }\end{array}$ & $\begin{array}{l}\text { Ranking } \\
1=\text { significant } \\
2=\text { not significant }\end{array}$ \\
\hline \multirow[t]{3}{*}{ Social } & Human Health & $\mathrm{HH}$ & $\begin{array}{l}\text { Life deterioration due to the implementation of } \\
\text { the technology. }\end{array}$ & DALY/TWh \\
\hline & Social acceptance & SA & $\begin{array}{l}\text { Positive opinions related to the implementation } \\
\text { of the technology. }\end{array}$ & 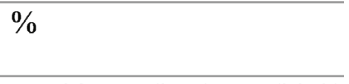 \\
\hline & Job creation potential & JC & $\begin{array}{l}\text { Direct employment created over the entire } \\
\text { lifecycle of the system per installed capacity. }\end{array}$ & Ranking 1 (low) -3 (high) \\
\hline
\end{tabular}

Table II summarizes the final set of criteria, including respective definition and methodology of evaluation and Table III assigns the scores obtained from literature research and qualitative assumptions considered in the MCDA. 


\section{TABLE III \\ FINAL SET OF CRITERIA FOR POWER GENERATION TECHNOLOGIES WITH CONSIDERED SCALES OBTAINED FROM LITERATURE AND QUALITATIVE ASSUMPTIONS}

Abbreviations: $B G$ = Biogas power, $D G$ = Diesel generator, $M H P=$ Micro-hydropower, MGT = Micro-gasturbine, $M W T=$ Micro-windturbine, $F C=$ Fuel cell, off-site generation of hydrogen (natural gas reforming), RFC = Regenerative fuel cell, on-site generation of hydrogen .

\begin{tabular}{|c|c|c|c|c|c|c|c|c|c|c|c|}
\hline Dimension & $\begin{array}{l}\text { Abbrevia } \\
\text { tion }\end{array}$ & Unit & BG & DG & MHP & MGT & MWT & PV & FC & RFC & Sources \\
\hline \multirow[t]{7}{*}{ Technical } & Eff & $\%$ & 33 & 37 & 70 & 23 & 35 & 22 & 50 & 21 & {$[34,44,45,48-54$} \\
\hline & AtD & R 1-3 & 2 & 3 & 1 & 3 & 1 & 1 & 3 & 3 & $\begin{array}{l}{[7,34,38,44,47,} \\
53,55,56]\end{array}$ \\
\hline & AtSE & R 1-3 & 3 & 2 & 1 & 2 & 1 & 1 & 2 & 3 & {$[7,8,39,57-59]$} \\
\hline & RA & R 1-5 & 2 & 5 & 2 & 5 & 3 & 4 & 5 & 4 & {$[48,55,60]$} \\
\hline & Mat & R 1-4 & 2 & 4 & 3 & 4 & 3 & 4 & 2 & 2 & $\begin{array}{l}{[7,34,38,44,47,} \\
53,55,56]\end{array}$ \\
\hline & $\mathrm{CF}$ & $\%$ & 74 & 73 & 52 & 80 & 28 & 21 & 76 & 76 & {$[34,49,59,61-65$} \\
\hline & $\mathrm{Lt}$ & $\mathrm{Y}$ & 10 & 10 & 30 & 20 & 20 & 20 & 15 & 15 & {$[7,49,66,67]$} \\
\hline Economic & LCOE & $\$ / \mathrm{kWh}$ & 0.15 & 0.46 & 0.15 & 0.31 & 0.28 & 0.31 & 0.26 & 0.5 & $\begin{array}{l}{[31,45,49,55,65} \\
67-76]\end{array}$ \\
\hline \multirow[t]{4}{*}{$\begin{array}{l}\text { Environ- } \\
\text { mental }\end{array}$} & LC-GHG & $\begin{array}{l}\mathrm{gCO}_{2-} \\
\mathrm{eq} / \mathrm{kWh}\end{array}$ & 145 & 1,000 & 23 & 460 & 25 & 90 & 520 & 400 & {$[77-88]$} \\
\hline & WR & 1/MWh & 920 & 2,100 & 7 & 1,000 & 4 & 165 & 2,400 & 465 & {$[78,89-94]$} \\
\hline & $\mathrm{LU}$ & $\mathrm{m}^{3} / \mathrm{MWH}$ & 170 & 4 & 2 & 4 & 4 & 20 & 4 & 12 & {$[34,87,91,94-97$} \\
\hline & NV & R 1-2 & 2 & 1 & 2 & 1 & 1 & 2 & 2 & 2 & {$[97-99]$} \\
\hline \multirow[t]{3}{*}{ Social } & $\mathrm{HH}$ & DALY/TWh & 50 & 20 & 10 & 15 & 25 & 60 & 58 & 68 & [100-103] \\
\hline & SA & $\%$ & 43 & 19 & 43 & 19 & 43 & 61 & 31 & 43 & {$[104,105]$} \\
\hline & $\mathrm{JP}$ & R 1-3 & 3 & 1 & 1 & 1 & 2 & 3 & 2 & 5 & {$[72,106-108]$} \\
\hline
\end{tabular}

Notably, hydrogen to power the fuel cell receiving external supply is thought to be produced by natural gas reforming, as this process still accounts for $95 \%$ of the generated hydrogen today [10]. As data on social acceptance is scarce, the system is estimated to be only little more [57] excepted by the population, as no local emissions occur. Further, the regenerative fuel cell even though defined as renewable technology - is also estimated to have a comparatively low acceptance, as the technology is not well known in the context.

The original data were normalized to a utility value on a dimensionless scale of 0 to 1 for within each criterion to allow for subsequent processing. Since explicitly aiming to capture any outliers, min-max normalization was applied. In this method for every criteria, the minimum value of that criteria is transformed into a 0 , the maximum value gets transformed into a 1 , and any other value is transformed into a decimal in between 0 and 1. The normalized value $\boldsymbol{x}_{\text {norm }}$ of original value $\boldsymbol{x}$ of criteria $\boldsymbol{i}$ is calculated by using the maximum $\max \left(\boldsymbol{x}_{\boldsymbol{i}}\right)$ and minimum $\min \left(\boldsymbol{x}_{\boldsymbol{i}}\right)$ values of the criteria span via equation 3 :

$$
x_{n o r m, i}=\frac{x_{i}-\min \left(x_{i}\right)}{\max \left(x_{i}\right)-\min \left(x_{i}\right)}
$$

For such criteria that correlate negatively with sustainability and therefore maximum value 1 would be undesirable, minuend and subtrahend in the numerator are switched.

\section{Scenario Development}

Even though the set of criteria defined for evaluation is as comprehensive as possible and as exhaustive as necessary, not all the criteria included might be equally important to assess the suitability of a technology. Further the technologies and settings might in future undergo potential development, influencing underlying parameter. To take account for these aspects three scenarios were developed, which shed light on respective foci. All the scenarios make use of introducing weights according to the rank-order weights approach. This weighting method implies that different weights should be attributed to the various criteria, so that $w_{1} \geq w_{2} \geq \ldots \geq w_{n} \geq 0$ with $\sum_{\boldsymbol{i}=\mathbf{1}}^{\boldsymbol{n}} \boldsymbol{w}_{\boldsymbol{i}}=\mathbf{1}$. The different scenarios and their rationale are briefly described below.

\section{a) Scenario 1: Strategically Important Criteria according to Expert Weights}

To detect and include strategically important criteria, thereby suiting the analysis to a close-to-reality perspective, a survey has been conducted along academic experts. 68 academics, which have published relevant work on rural electrification in SSA in scientific journals within the period of 2015 to 2021 have been approached via email. The response rate was 31\% with 21 valid answers on the complete survey, of from which the majority (38\%) hold a professorship or work as a research associate (29\%). The exact questions as well as statistics of the questionnaire can be viewed in detail in Appendix B. 
In a first step the respondent's level of familiarity with issues regarding SDG 7, minigrids and hydrogen technologies was assessed to validate the answers later on. The subsequent main questionnaire composed two major sections. At first, the respondents were asked to give their opinion on importance of the respective evaluation criteria given in Table II. As it allows for slight potential future modifications, the simple multi-attribute rating technique - extended rating (SMARTER) was adopted for this purpose. With this, the respondents were asked to place the $n$ criteria $\boldsymbol{C}$ into an importance order: $\boldsymbol{C}_{\mathbf{1}}>\boldsymbol{C}_{\mathbf{2}}>\ldots>\boldsymbol{C}_{\boldsymbol{n}}$

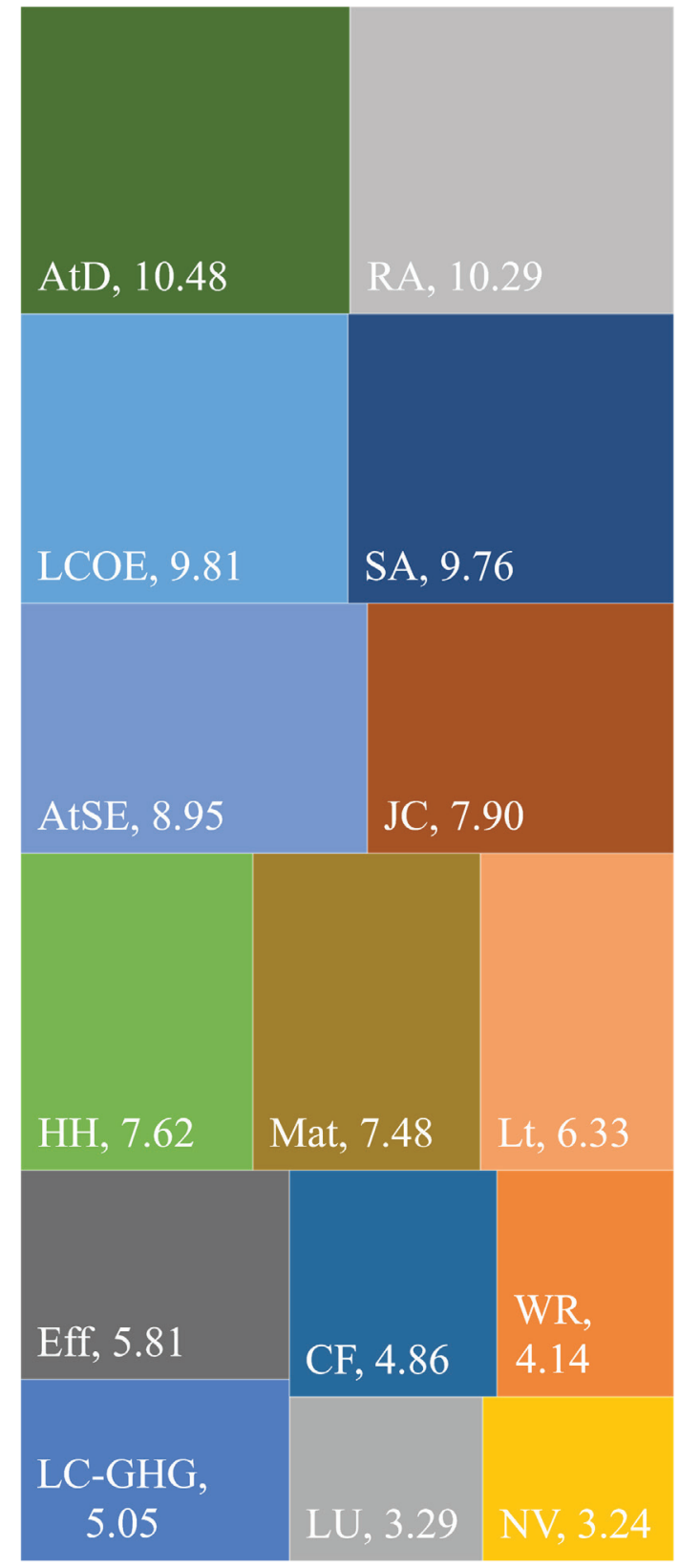

Fig. 3. Average ranking of the criteria obtained from the expert survey. LCOE = Levelized costs of electricity, HHE = Human health effect, $S A=$ Social acceptance, $J C=$ Job creation potential, Eff $=$ Electrical efficiency, Mat = Maturity, $D F=$ Capacity factor, RtD = Ability to respond to demand, AtSE = Ability to serve multiple end-uses, Lt = Lifetime, $R A=$ Resource availability, LC-GHG = Lifecycle GHG emission, $W R=$ Water resource use, $L U=$ Land use, $N V=$ Noise and visual pollution.
Figure 3 illustrates the average ranking of all criteria according to the expert survey. With the Ability to respond to Demand (AtD, 10.48) and Resource Availability (RA, 10.29), two technical criteria are estimated to be most important, just before the economic criteria of Levelized Costs of Electricity (LCOE, 9.81). Social Acceptance (SA, 9.76) and Ability to serve multiple end-uses (AtSE, 8.95) rank just behind. The impression of environmental belongings being least important compared to criteria of other dimension, are confirmed by repeating the question on estimated importance on the dimensions of sustainability. Economic dimension ranks before social and technical dimension, while environmental dimension is significantly outranked.

To specifically highlight any extreme and allow for more difference in the results, the average ranking of criteria was again normalized using min-max normalization before applying the weights to the MCDA. Table IV summarizes the applied weights.

\section{b) Scenario 2: Market decisive criteria}

The experts' assessment of decisive criteria for the choice of technology may - especially because of their academic background - suggest a fictitious optimum that does not necessarily correspond to the view of market actors, such as minigrid developers. External factors can limit a theoretically optimal choice of technology, leading to other criteria to become more important. To take such constraints into account a scenario was developed, giving more emphasis on criteria in which currently market dominating technologies are strong in - as these criteria might be reason for their market dominance.

Even though for some countries it appears to deviate, the overall picture of SSA shows the diesel generator and solar PV to hold major market shares [56, 109]. In fact, solar hybrid mini-grids are the most dominant form of modern mini-grids installed today[56], which already leads to the obvious conclusion of resource availability being restrictive factor. The normalized values of data applied in the analysis reveals the diesel generator to perform the best of all technologies in maturity - which is also associated to market availability and supply chain - ability to respond to demand and resource availability. PV also performs well in maturity, further in social acceptance, job creation potential and noise and visual pollution. Amongst the renewable energies PV has highest resource availability on the African continent [60]. With this, the scenario focuses on these criteria by increasing their weights by a factor of three. Table IV includes the weights accordingly. 


\section{c) Scenario 3: Future evolution scenario}

Hydrogen technologies at the present state are at a comparatively low stage of maturity, including both technical and market related aspects. However, not only the technologies themselves might undergo future development, but also policies will affect the technologies' market environment. To take such development into account, a future scenario was constructed.

The scenario includes change in technology parameter according to prominent literature as well as emphasis on weights the authors see in alignment with the current policies. Major assumptions for this evolution scenario, taking place in 2040, are

- External hydrogen supply is assumed to be produced by large-scale water electrolysis plant with production costs of at least $1 \$ / \mathrm{kg}-2.1 \$ / \mathrm{kg}$ [68]. Including fuel logistics and conversion the researchers assume LCOE of $0.24 \$ / \mathrm{kWh}$ [31].

- LCOE of on-site produced hydrogen are expected to fall with increased technology maturity to $0.44 \$ / \mathrm{kWh}[31,68]$.

- Efficiencies are expected to increase for PV and hydrogen technologies by $30 \%$.

- Improvements to reduce carbon footprint for fossil fuels can be made [51].

- $\quad$ Prices for renewable energies are expected to decrease by $30 \%$ as of 2040 [110].
- Impact of climate change could decrease resource availability for water resources and biomass resources.

- Fossil resources are expected to decrease, deteriorating the resource availability of diesel generator and micro-gasturbine.

According to the predominant global policy objectives, the authors assume especially such criteria to be more important in future, which are aligned with the UN SDGs. Therefore, weights are increased by a factor of two for such criteria that are explicitly linked to the rationale of SDG targets. These are Life-cycle GHG emissions (SDG 13 Climate Action), Water resource use (SDG 6 Clean Water and Sanitation), Land use (SDG 15 Life on Land), Human Health Effect (SDG 3 Good Health and Well-being), Job creation potential (SDG 8 Decent Work and Economic Growth), LCOE (SDG 7 Affordable and Clean Energy), Electrical efficiency (SDG 7 Affordable and Clean Energy) and Ability to serve multiple end-uses (SDG 12 Responsible Consumption and Production). The criterion of maturity was excluded from the analysis, as future development and respective stages of maturity remains uncertain. Further, when assuming all technologies to have reached high market maturity by 2040, the criterion would violate the comparability principle (see section B Criteria Selection). An overview of all scenario weights is given in Table IV.

\section{TABLE IV \\ SUMMARY OF WEIGHTS APPLIED ACCORDING TO THE DIFFERENT SCENARIOS}

LCOE = Levelized costs of electricity, HHE = Human health effect, SA = Social acceptance, JC = Job creation potential, Eff = Electrical efficiency, Mat $=$ Maturity, $D F=$ Capacity factor, $R t D=$ Ability to respond to demand, AtSE $=$ Ability to serve multiple end-uses, Lt $=$ Lifetime, $R A=$ Resource availability, LC-GHG = Lifecycle GHG emission, $W R=$ Water resource use, $L U=$ Land use, $N V=$ Noise and visual pollution.

\begin{tabular}{llllllllllllllll}
\hline & $\begin{array}{l}\text { LC- } \\
\text { GHG }\end{array}$ & WR & LU & NV & LCOE & HH & SA & JC & Eff & Mat & CF & AtD & AtSE & LT & RA \\
\hline $\begin{array}{l}\text { Expert } \\
\text { weights }\end{array}$ & 0.25 & 0.125 & 0.007 & 0 & 0.91 & 0.6 & 0.9 & 0.64 & 0.36 & 0.59 & 0.2 & 1 & 0.79 & 0.43 & 0.97 \\
\hline $\begin{array}{l}\text { Market } \\
\text { dominant }\end{array}$ & 1 & 1 & 1 & 3 & 1 & 1 & 3 & 3 & 1 & 3 & 1 & 3 & 1 & 1 & 3 \\
\hline $\begin{array}{l}\text { Future } \\
2040\end{array}$ & 2 & 2 & 2 & 1 & 2 & 2 & 1 & 2 & 2 & 0 & 1 & 1 & 2 & 1 & 1 \\
\hline
\end{tabular}

\section{MCDA Ranking}

Applying the weights to the criteria results in an overall ranking of the technologies. Popular weighted arithmetic mean (WAM) method was chosen for aggregation, which calculates the weighted average $\boldsymbol{x}_{\boldsymbol{w a}}$ with the weights $\boldsymbol{w}_{\boldsymbol{i}}$ applied to criteria values $\boldsymbol{x}_{\boldsymbol{i}}$ by equation 4

$$
x_{w a}=\frac{\sum_{i=1}^{n} w_{i} x_{i}}{\sum_{i=1}^{n} w_{i}}
$$

In energy related research most common method is to apply equal weights [35], which was adopted for this paper to serve as reference point for the different scenarios to compare with. 


\section{RESULTS}

\section{A. Strengths and Weaknesses of Fuel Cells}

First results and implications from the analysis can already be drawn from observing the normalized scores of the fuel cell within the different evaluation criteria. These normalized scores indicate the relative performance of the technologies in the respective discipline compared to the alternative technologies. Figure 4 illustrates this performance disaggregated for the fuel cell powered by hydrogen from external natural gas reforming, and the regenerative fuel cell, which generates hydrogen on-site assuming the best renewable primary power source in each criterion. The graph reads that above the abscissa is the relative positive deviation from the average of the technologies in the respective criterion. Conversely bars below the abscissa indicate a deviation to the negative. The height of the bars quantifies the relative distance from the average. If the bars meet the respective dashed lines, it implies that the technology in the considered categories performs best - for those bars that are above the abscissa - or performs worst - for those bars that are below the abscissa.

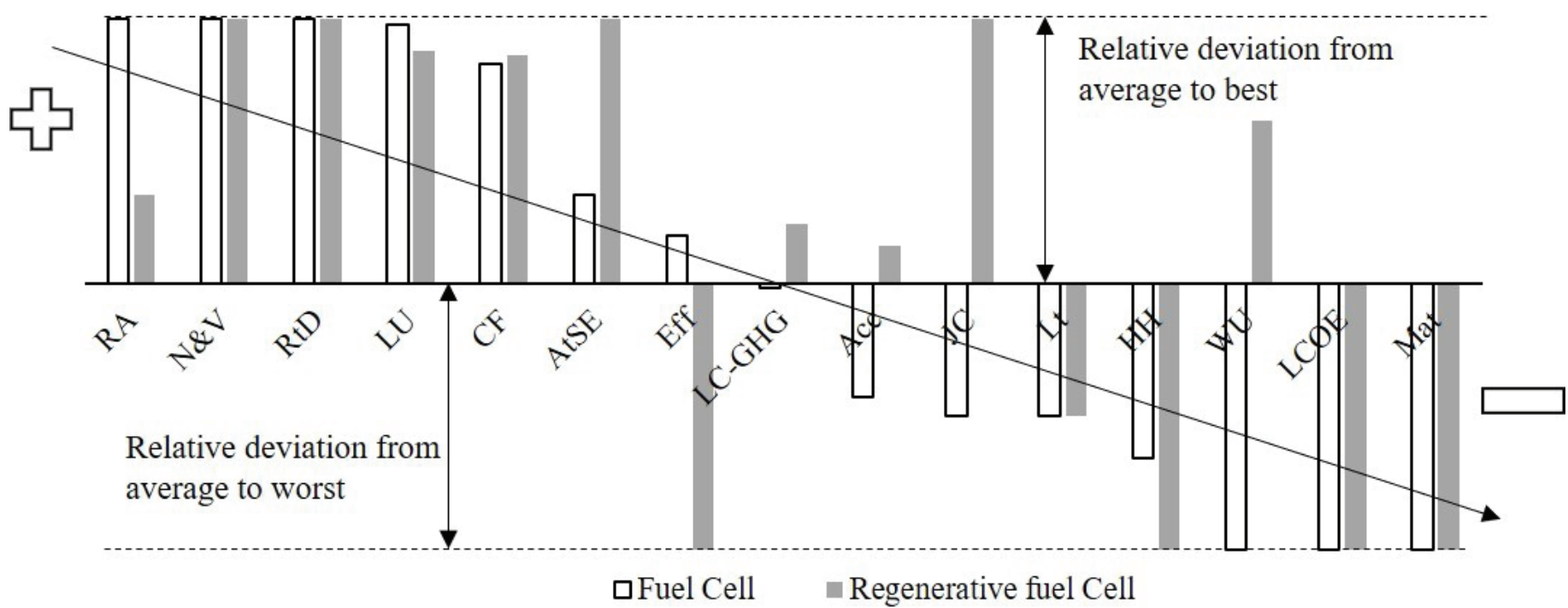

Fig. 4 Relative performance of the fuel cell and regenerative fuel cell in respective criteria.

LCOE = Levelized costs of electricity, HHE = Human health effect, $S A=$ Social acceptance, JC = Job creation potential, Eff = Electrical efficiency, Mat = Maturity, $D F=$ Capacity factor, RtD = Ability to respond to demand, AtsE = Ability to serve multiple end-uses, Lt $=$ Lifetime, RA = Resource availability, $L C-G H G=$ Lifecycle GHG emission, $W R=$ Water resource use, $L U=$ Land use, $N V=$ Noise and visual pollution

The figure indicates that both options of fuel cells are least mature and have the highest LCOE, which summarizes overall economic performance in the study. Also, both alternatives perform comparatively low in the effect on human health. This is due to the fact that hydrogen technologies require a significant amount of raw materials, whose mining processes are potentially harmful to health. As the paper covers for - in this sense - the worst case of on-site production of hydrogen, a separate electrolyzer and fuel cell summarized as regenerative fuel cell performs even worse than a stand-alone fuel cell in this discipline. In contrast to any other renewable power generation technologies, the results indicate that both fuel cell integration topologies have the highest possibility to respond to demand, as fuel cells can operate

dynamically [7, 44]. Resource availability of natural to fuel the stand-alone fuel cell is still assumed to be without major risks by now. The resource availability of the on-site produced hydrogen depends on the best available renewable primary electricity source.

\section{B. Technology Ranking}

As a common practice to present results of MCDA, Figure 5 illustrates a ranking of the technologies. The figure plots the normalized and weighted aggregated values of all criteria applied in the analysis. The ranking was performed for each of the beforementioned scenarios of: 1 . weights according to the expert survey (grey bars), 2. weights increased for criteria decisive for market penetration (market decisive criteria) (crosshatched bars) and 3. parameter and weights adjusted according to estimated future development (black bars). To allow for better comparison and discussion, the blank bars illustrate the ranking when applying equal weights to all criteria. 


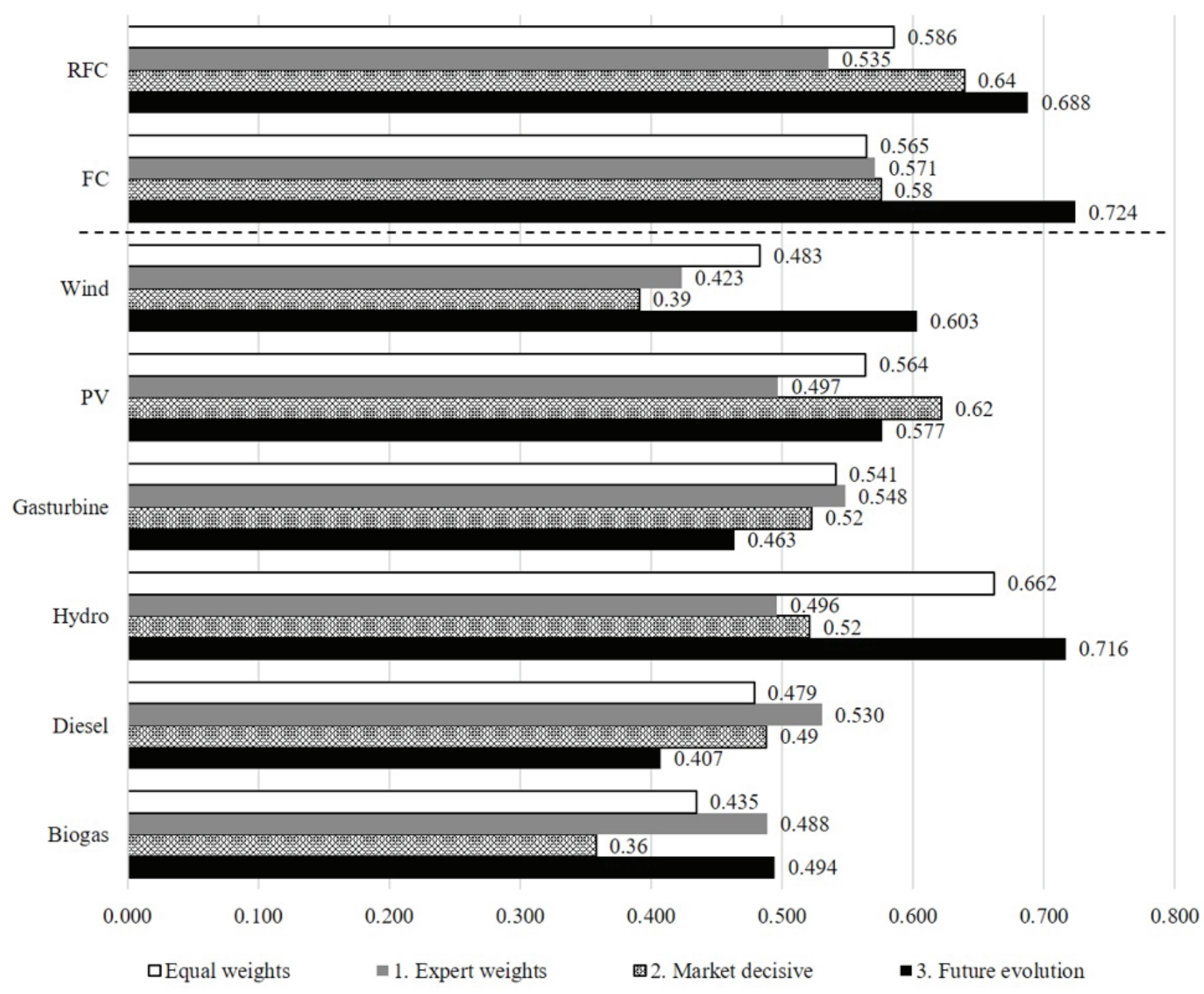

Fig. 5 Sustainability ranking of the power generation technologies for applying equal weights and applying the predefined scenarios.

\section{Scenario 1: strategically important criteria: expert weights}

Applying weights according to allocation of the consulted academic experts, as explained in the methods section, results in the fuel cell supplied with external produced hydrogen from natural gas reforming to rank first (0.571). The next most suitable power generation technologies for rural minigrids according to the analysis are microgasturbine (0.548), the regenerative fuel cell producing hydrogen on-site (0.535) and the diesel generator $(0.53)$. Established renewable technologies rank behind the fossil competitors, with PV (0.497) and micro-hydropower (0.496) ranking before biogas power (0.488) and the least suitable technology of micro-windpower (0.423).

\section{Scenario 2: market decisive criteria}

Shifting weights towards such criteria being decisive for high market shares today ranks the regenerative fuel cell (0.64) just before PV (0.62). The stand-alone fuel cell improves slightly compared to an equal weight scenario, leveling on third place (0.58) just before micro-gasturbine and micro-hydropower (both 0.52). Biogaspower ends up in the last place (0.36).

\section{Scenario 3: future evolution}

According to the future scenario with parameter and weights applied to estimated future development, the stand-alone fuel cell - notably powered by hydrogen from large scale water electrolysis in this scenario - is the most suitable technology for power supply in rural minigrids (0.724). The fuel cell is closely followed by microhydro power (0.716) and the decentralized regenerative fuel cell (0.688). Fossil fuel-based technologies microgasturbine (0.463) and diesel generator (0.407) are significantly outranked by renewable power generation technologies. 


\section{DISCUSSION}

The discussion will at first deepen the results of the technology ranking with paying particular attention to the performance of hydrogen technologies. Subsequently extracts of the expert survey will be presented to include some prominent points of discussion regarding the application of hydrogen in SSA minigrids.

Against previous studies, which only considered economic performance of technologies (a.o. [27]), this MCDA analysis indicates that hydrogen technologies are highly suitable for power supply in SSA minigrids. Both studied alternative systems, the stand-alone fuel cell supplied with external produced hydrogen and the system considering on-site generation of hydrogen, rank among the top three technologies in each defined scenario.

In the first scenario weights were applied according to the suggestions of academic experts. With this, the weights have relatively increased especially for the ability to respond to demand, resource availability, LCOE, social acceptance and the ability to serve multiple end-uses. The two first mentioned and thereby most important criteria are especially met by fossil fuel-based technologies, but also the stand-alone fuel cell supplied by hydrogen from natural gas reforming, which conclusively benefits from increasing the weights. Also, LCOE of this fuel cell topology $(0.26 \$ / \mathrm{kWh})$ is competitive to other technologies, while social acceptance is assumed to be only slightly higher than the already biased fossil technologies, e.g. diesel generator.

Considering the on-site generation of hydrogen however, the ability to respond to demand is not affected and still at maximum of the applied scale. However, resource availability deteriorates compared to fossil fuels and LCOE increases significantly. As the weights for these criteria have increased, the aggregated score of the reversible fuel cell decreases. Neither the social acceptance - estimated to be lower than other renewables, as the fuel cell technology in general is not very well known - nor the outstanding ability to provide multiple end-uses can compensate for the losses. However, the latter must be emphasized, as it can become a strategically important capability in the future.

As e.g. Topriska et al. $[8,111]$ proposed in previous studies, the usage of on-site produced hydrogen as clean cooking fuel is technically viable and can cause major benefits to the users, especially concerning health. Still facing a huge gap in the aim to provide clean cooking fuels to all people by 2030 in SSA [3], the expanded usage of hydrogen not only for power generation but also as cooking fuel must be investigated for possible synergies in subsequent work.

Additional finding of the scenario is that other renewable technologies are not suitable without additional storage components. Especially the important criteria of resource availability and ability to respond to demand are not reflected by the standalone systems.

However, for all previous discussions it must be noted that the indications of the experts on strategically important criteria can be assumed to be neutral - as the vast majority of $72 \%$ is employed at an academic institution - but also might not reflect the opinion of actual minigrid deployer and investors.

To overcome this potential limitation, the second scenario sheds light on such criteria in which current market dominating PV and diesel generator perform best in. These include maturity, ability to respond to demand, resource availability, social acceptance, job creation potential and noise and visual pollution. Not surprisingly, the results demonstrate a strong position of PV in comparison to other technologies. Notably, the regenerative fuel cell system border includes an upstream renewable power generation technology, as explained in the material and methods section. Therefore, advantages of PV in this scenario are also reflected by this system topology, which ends-up slightly before PV. However, also the stand-alone fuel cell ranks among the top-three in this weighting scenario, as again ability to respond to demand and resource availability appear to be decisive.

As with this both technologies perform well in the ranking not only when applying weights according to impartial academic experts but also when emphasizing criteria decisive for actual market share, the results from the MCDA suggests that hydrogen technologies are indeed suitable for rural minigrids and competitive to other technologies.

The MCDA results from applying parameter and weights according to the future scenario, which notably includes the stand-alone fuel cell to be supplied from large scale water electrolysis plants, indicate the future potential of such technologies. As such large-scale production of hydrogen has the potential to reduce LCOE significantly, benefitting from the economy of scale effects, the stand-alone system outranks the on-site production of hydrogen.

As an aside, from this future scenario it must be noted that micro-hydropower significantly improves in the ranking from applying future parameter and weights according to sustainable development policies. This result supports the estimation of the SE4All initiative which suggests micro-hydropower to be an emerging technology for future minigrid development also in SSA [56].

In contrast to the indications of the MCDA findings, the consulted experts of the survey in general are not convinced that fuel cells play a major role to supply power to rural SSA minigrids in future. The question on "What is the likelihood that hydrogen 
technologies will find application in rural minigrids as a widespread solution in the future?" was answered with "Not very likely, but possible" by a slight majority of $57 \%$. However, only $16 \%$ of the respondents answer the same question with "Very likely". Major concerns of the experts refer to low technology maturity and economic performance. This supports the impression that financial aspects and supply-chain issues are still most important for actual market penetration of a technology. As the first point of criticism - maturity - is only ranked 8th on average as most decisive criteria for minigrid technologies in the expert survey (compared to Figure 3), this effect is not very much represented in the results from scenario 1.

The latter however - low economic performance - is supported by the considerations for the onsite production of hydrogen especially. However, assuming only the fuel cell to be decentralized while hydrogen production takes place in large scale water electrolysis plants - as considered in scenario 3 -, the technologies could become cost competitive. Nevertheless, as the development of such largescale plants involve substantial financial investment and political support, this development is not likely to be in hands of minigrid developers. The authors rather suggest investigating economic niches for decentralized hydrogen production - such as local phenomena of excess electricity - and improvements in system integration in future work. Also, potential benefits from fuel flexibility and connections to other sectors, both of which stated as major benefits by the consulted experts, should be followed. For the extensive set of comments given by the experts see Appendix B.

\section{CONCLUSIONS}

The study aimed to provide a comprehensive sustainability assessment of fuel cells and a set of power generating technologies in rural SSA minigrids, using multi-criteria decision analysis. The approach - opposed to previous works - opens the discussion on the fit of hydrogen technologies for this purpose to include not only economic or technical concerns but also social and environmental aspects which a technology touches on in electrification. The development of different scenarios additionally sheds light on: 1. strategically important criteria according to academic expert estimations, 2.

criteria decisive for actual market penetration of power generation technologies in minigrids and 3. future parameter and criteria in alliance with sustainable development.

The findings indicate the fuel cell to be highly suitable for rural power generation in SSA minigrids. In each scenario both considered fuel cell integration alternatives of on-site and off-site generation of hydrogen rank amongst the top three technologies. Findings of the last scenario suggest the largescale electrolysis and supply of decentralized fuel cells to be advantageous against decentralized production, as the LCOE can be decreased. However, as this is neither in hands of minigrid developers nor foreseeable in near future, economic niches and usecases for decentralized production must be defined. Findings from the MCDA and comments given by academic experts in a survey suggest such objects of investigation to be local phenomena, such as excess electricity, expanded usage of hydrogen on other sectors with associated business models and flexible fuel usage.

On the mission to close the gap for rural electrification until 2030, it is important to already create long lasting sustainable solutions and avoid any extensive future modifications of energy systems. Therefore, energy system developer must think the systems with perspective on potential future development of the people and region of concern, leaving no future limitations for the user. Considering electricity supply, for Solar Home Systems, this implies to study a future interconnection of the single appliances to a "swarm" [112]. First studies on this system design promise to increase the reliability of supply and decrease overall LCOE [112]. For minigrids deployed today it means to already consider future grid connection, leaving the challenge to design the system appropriately that it is of value still, "when the grid arrives". Additionally, considering other needs of the people and region of concern, energy system decision maker should integrate possible solutions out of the various fields of human development in the energy system planning process. This may include other energy vectors, such as clean cooking or transportation services but also non-energy related topics such as food supply. Previous works have extensively shown the various (positive and negative) interlinkages of SDG7 and other fields of development (a.o. [33, 113]). Such studies must find their way into energy system planning to create sustainable and impactful energy supply, beyond the SDG period.

\section{ACKNOWLEDGMENT}

The authors sincerely express their gratitude to all the experts who participated in the survey and contributed their knowledge and expertise to shape the analysis.

\section{COMPETING INTERESTS}

The authors declare that they have no competing interests. 


\section{APPENDIX}

Appendix A: Spearman's rank coefficient of initial set of criteria

TABLE A.1

SPEARMAN'S RANK COEFFICIENT FOR CRITERIA OF THE TECHNICAL DIMENSION. EXCLUDED FROM THE SET ARE ENERGY EFFICIENCY, INFRASTRUCTURE FKEXIBILITY, WEATHER AND CLIMATE DEPENDENCY< DEPENDENCY ON FOSSIL FUELS.

\begin{tabular}{|c|c|c|c|c|c|c|c|c|c|c|c|c|c|}
\hline Variable & & $\begin{array}{l}\text { Electrical } \\
\text { efficiency. }\end{array}$ & \begin{tabular}{|l} 
Energy \\
efficiency
\end{tabular} & \begin{tabular}{|l|} 
Ability \\
to \\
respond \\
to \\
demand
\end{tabular} & \begin{tabular}{|l|} 
Ability to \\
provide \\
multiple \\
end-use \\
services
\end{tabular} & $\begin{array}{l}\text { Infrastru } \\
\text { cture } \\
\text { flexibility }\end{array}$ & $\begin{array}{l}\text { Weathe } \\
\text { and clin } \\
\text { conditi } \\
\text { depend }\end{array}$ & & $\begin{array}{l}\text { Resourc } \\
\text { availabil } \\
\mathbf{y}\end{array}$ & Maturity & $\begin{array}{l}\text { Capacity } \\
\text { factor }\end{array}$ & Lifetime & $\begin{array}{l}\text { Dependence } \\
\text { on fossil fuel }\end{array}$ \\
\hline & & & & & & & & & & & & & \\
\hline $\begin{array}{l}\text { 1. Electrical } \\
\text { efficiency. }\end{array}$ & \begin{tabular}{|l|} 
\\
Spearman' \\
s rho
\end{tabular} & - & & & & & & & & & & & \\
\hline $\begin{array}{l}\text { 2. Energy } \\
\text { efficiency }\end{array}$ & \begin{tabular}{|l|}
$\begin{array}{l}\text { Spearman' } \\
\text { s rho }\end{array}$ \\
\end{tabular} & 0.164 & - & & & & & & & & & & \\
\hline $\begin{array}{l}\text { 3. Ability to } \\
\text { respond to } \\
\text { demand }\end{array}$ & $\begin{array}{l}\text { Spearman' } \\
\text { s rho }\end{array}$ & -0.154 & 0.432 & - & & & & & & & & & \\
\hline $\begin{array}{l}\text { 4. Ability to } \\
\text { provide } \\
\text { multiple } \\
\text { end-use } \\
\text { services }\end{array}$ & \begin{tabular}{|l|} 
Spearman' \\
s rho
\end{tabular} & -0.170 & 0.539 & 0.776 & - & & & & & & & & \\
\hline $\begin{array}{l}5 . \\
\text { Infrastructur } \\
\text { e flexibility }\end{array}$ & \begin{tabular}{|l} 
Spearman' \\
s rho
\end{tabular} & $\mid-0.179$ & -0.548 & -0.473 & -0.843 & - & & & & & & & \\
\hline $\begin{array}{l}\text { 6. Weather } \\
\text { and climatic } \\
\text { condition } \\
\text { dependence }\end{array}$ & $\begin{array}{l}\text { Spearman' } \\
\text { s rho }\end{array}$ & 0.189 & 0.674 & 0.816 & 0.500 & -0.264 & - & & & & & & \\
\hline $\begin{array}{l}\text { 7. Resource } \\
\text { availability }\end{array}$ & $\begin{array}{l}\text { Spearman' } \\
\text { s rho }\end{array}$ & -0.385 & -0.131 & 0.674 & 0.136 & 0.297 & 0.534 & & - & & & & \\
\hline 8. Maturity & \begin{tabular}{|l} 
Spearman' \\
s rho
\end{tabular} & -0.208 & -0.250 & 0.041 & -0.500 & 0.843 & 0.250 & & 0.690 & - & & & \\
\hline $\begin{array}{l}\text { 9. Capacity } \\
\text { factor }\end{array}$ & \begin{tabular}{|l|} 
\\
Spearman' \\
s rho
\end{tabular} & -0.143 & 0.764 & 0.849 & 0.794 & -0.657 & 0.756 & & 0.330 & -0.227 & - & & \\
\hline 10. Lifetime & $\begin{array}{l}\text { Spearman' } \\
\text { s rho }\end{array}$ & 0.131 & -0.210 & -0.566 & -0.852 & 0.668 & -0.248 & & -0.096 & 0.406 & -0.412 & - & \\
\hline $\begin{array}{l}11 . \\
\text { Dependence } \\
\text { on fossil } \\
\text { fuel }\end{array}$ & \begin{tabular}{|l|} 
\\
Spearman' \\
s rho
\end{tabular} & 0.000 & -0.322 & -0.683 & -0.167 & -0.176 & -0.837 & & -0.813 & -0.669 & -0.474 & 0.083 & - \\
\hline
\end{tabular}


TABLE A.2

SPEARMAN"S RANK COEFFICIENT FOR CRITERIA OF THE ECONOMIC DIMENSION. EXCLUDED FROM THE SET ARE INVESTMENT COSTS AND LCOE DO NOT EXCEED THE THREASHOLD OF 0.6, BUT AR INTERWINED BY THEIR DEFINITIN

\begin{tabular}{|lcccc}
\hline Variable & LCOE & Invest & O\&M & Fuel \\
1. LCOE & - & & & \\
2. Invest & -0.468 & - & & \\
3. O\&M & -0.673 & 0.847 & - & \\
4. Fuel & 0.748 & -0.809 & -0.668 & - \\
\hline
\end{tabular}

TABLE A.3

SPEARMAN'S RANK COEFFICIENT FOR CRITERIA OF THE ENVIRONMENTAL DIMENSION. EXCLUDED FROM THE SET ARE LOCAL GHG EMISSION, RENEWABLE ENERGY.

\begin{tabular}{|l|l|l|l|l|l|l|l}
\hline Variable & $\begin{array}{l}\text { Local GHG } \\
\text { emissions }\end{array}$ & $\begin{array}{l}\text { Life cycle GHG } \\
\text { emission }\end{array}$ & $\begin{array}{l}\text { Renewable } \\
\text { Resource }\end{array}$ & $\begin{array}{l}\text { Impact on water } \\
\text { resources }\end{array}$ & $\begin{array}{l}\text { Land } \\
\text { use }\end{array}$ & $\begin{array}{l}\text { Noise \& visual } \\
\text { pollution }\end{array}$ \\
\hline $\begin{array}{l}\text { 1. Local GHG } \\
\text { emissions }\end{array}$ & - & & & & & \\
\hline $\begin{array}{l}\text { 2. Life cycle GHG } \\
\text { emission }\end{array}$ & 0.802 & - & & & & \\
\hline $\begin{array}{l}\text { 3. Renewable } \\
\text { Resource }\end{array}$ & -0.986 & -0.791 & - & - & & \\
\hline $\begin{array}{l}\text { 4. Impact on water } \\
\text { resources }\end{array}$ & 0.802 & 0.929 & -0.791 & - & & \\
\hline 5. Land use & -0.324 & 0.185 & 0.328 & 0.185 & - & \\
\hline $\begin{array}{l}\text { 6. Noise \& visual } \\
\text { pollution }\end{array}$ & -0.540 & -0.433 & 0.548 & -0.433 & 0.000 & - \\
\hline
\end{tabular}

TABLE A.4

SPEARMAN'S RANK COEFFICIENT FOR CRITERIA OF THE SOCIAL DIMENSION. EXCLUDED FROM THE SET IS EXTERNAL SUPPU RISK.

\begin{tabular}{|c|c|c|c|c|}
\hline Variable & Job creation potential & $\begin{array}{c}\text { External supply } \\
\text { risk }\end{array}$ & Social acceptability & $\begin{array}{l}\text { Human } \\
\text { Health }\end{array}$ \\
\hline 1. Job creation potential & - & & & \\
\hline 2. External supply risk & 0.669 & - & & \\
\hline 3. Social acceptability & 0.769 & 0.882 & - & \\
\hline 4. Human Health & 0.869 & 0.474 & 0.657 & - \\
\hline
\end{tabular}

Appendix B: Questionnaire composition and response statistics

Valid answers: 21 (30.9\% response rate)

Section 1: Introduction

- How familiar are you with the issues concerning the electrification via minigrids?

Options: Rank from "not familiar at all" to "expert" on a 5-step scale.

1. Technologies for rural electrification: $1=4.8 \%, 2=4.8 \%, 3=14.3 \%, 4=42.9 \%, 5=33.3 \%$

2. Relation of access to electricity and development: $1=0 \%, 2=4.8 \%, 3=14.3 \%, 4=57.1 \%, 5=23.8 \%$

3. Sustainable Development Goal no. 7: $1=7.8 \%, 2=4.8 \%, 3=28.6 \%, 4=38.1 \%, 5=23.8 \%$

4. Multi-Tier framework for energy access: $1=9.5 \%, 2=19.0 \%, 3=23.8 \%, 4=33.3 \%, 5=14.3 \%$ 


\section{Section 2: Research type technologies}

- We would like you to choose the order of importance for technical, social, environmental and economic aspects of sustainable electrification through minigrids. Please order it depending on the importance you think it has from (1 - most important to 4 - least important).

Options: "Technical dimension", "Social dimension", "Environmental dimension", "Economic dimension". Average ranking: Technical dimension 2.7, Social dimension 2.3, Environmental dimension 3, Economic dimension 2.0.

- We would like you to choose the order of importance for the following sustainability criteria in sustainable electrification through minigrids. Please order it depending on the importance you think it has from (1 - most important to 15 - least important).

Options: See Table 4. Results see Figure 6.

\section{Section 3: Research type focus hydrogen}

- In your opinion, what is the likelihood that hydrogen technologies will find application in rural minigrids as a widespread solution in the future?

Options: "Not likely at all" (5\%), "Not very likely, but possible" (57\%), "Indifferent" (19\%), "Very likely" (14\%), "No doubt at all" (0\%).

- What obstacles do you see for hydrogen technologies to become a future solution in minigrids? Options: Free text. Answers: see Table 11.

- What are the strengths that you see for hydrogen technologies to become a future solution in minigrids?

Options: Free text. Answers: see Table 11.

\section{TABLE B.1 \\ SURVEY RESPONDENT's COMMENTS ON OBSTACLES (LEFT) AND POTENTIAL (RIGHT) OF HYDROGEN TECHNOLOGIES IN RURAL MINIGRIDS.}

\begin{tabular}{|c|c|}
\hline $\begin{array}{l}\text { What obstacles do you see for hydrogen technologies to become } \\
\text { a future solution in minigrids? }\end{array}$ & $\begin{array}{l}\text { What are the strengths that you see for hydrogen technologies } \\
\text { to become a future solution in minigrids? }\end{array}$ \\
\hline $\begin{array}{l}\text { Supply chain and infrastructure. Usually MG are very remote. } \\
\text { Renewable Energy should be easier and cheaper. }\end{array}$ & $\begin{array}{l}\text { A green alternative compared to Diesel or gas, but with the same } \\
\text { advantages for flexibility and disadvantages for logistics and price. }\end{array}$ \\
\hline $\begin{array}{l}\text { I think in Africa, this technology is not well considered by the } \\
\text { authorities. }\end{array}$ & Flexibility and efficiency \\
\hline $\begin{array}{l}\text { Technological maturation is not sufficient for hydrogen } \\
\text { technologies, yet. Also, not many communities/organizations are } \\
\text { familiar with the technology. }\end{array}$ & $\begin{array}{l}\text { The emissions of hydrogen technologies, and their land and water } \\
\text { resource usages are relatively lower than the existing technologies. }\end{array}$ \\
\hline Late comer & Resource flexibility \\
\hline $\begin{array}{l}\text { Costs, maturity / availability of technology; developers were } \\
\text { hesitant to use Li-Ion instead of L/A batteries because of lack of } \\
\text { field experience with the "new" technology. This will also happen } \\
\text { to } \mathrm{H} 2 \text {. }\end{array}$ & $\begin{array}{l}\text { Seasonal storage and connection to other sectors. but both } \\
\text { strengths do not really apply for mini-grids for electrification (no } \\
\text { seasonal variation in solar inradiation, no industrial } \mathrm{H} 2 \text { demands). }\end{array}$ \\
\hline $\begin{array}{l}\text {-Fuel cell and electrolyger option - currently too expensive with } \\
\text { low round-trip efficiency, and small scale primary power hydrogen } \\
\text { technologies are also less likely to get attention than larger scale } \\
\text { hydrogen technologies. } \\
\text {-Other storage technologies may reach maturity first even if not } \\
\text { fundamentally better suited - flow batteries or simply much } \\
\text { cheaper conventional chemical batteries, e.g. } \\
\text {-Greenhouse gas emission reduction goals not being a high priority } \\
\text { for developing countries - therefore the diesel is more attractive } \\
\text {-Public perception: New technology largely unproven in African } \\
\text { mini-grid context - several pilot rural minigrid projects have } \\
\text { already failed (South Africa as example) } \\
\text {-Additional complexity of system with additional integration } \\
\text { aspects - limited knowhow of maintenance and installation etc. } \\
\text { Electrolysis would also require distilled water gupply }\end{array}$ & $\begin{array}{l}\text {-Long term seasonal storage potentially allowing } 100 \% \text { renewable } \\
\text { energy systems. } \\
\text {-Cogeneration to recover heat losses } \\
\text {-Possibility of replacing existing diesel generators with hydrogen } \\
\text {-Centralized "green fuels" created from hydrogen and transported } \\
\text { to be used to replace diesel could have very interesting applications } \\
\text { if made economically viable } \\
\text { "Clean" with low or zero noise } \\
\text {-Global focus on hydrogen tech for net-zero etc, could have } \\
\text { spillover effects making hydrogen tech better universally and } \\
\text { therefore better for rural electrification etc. }\end{array}$ \\
\hline \multicolumn{2}{|l|}{$\begin{array}{l}\text { I don't think one would find the necessary capacities in Africa for } \\
\text { operation and maintenance. Also, storage systems are not the main } \\
\text { bottleneck of current minigrid projects, which often fail for other } \\
\text { reasons. }\end{array}$} \\
\hline $\begin{array}{l}\text {-cost (short term) } \\
\text {-technology } \\
\text {-awarenes5 } \\
\text {-acceptance } \\
\text {-gafety }\end{array}$ & $\begin{array}{l}\text {-cost (long term) } \\
\text {-power capacity }\end{array}$ \\
\hline
\end{tabular}




\begin{tabular}{|c|c|}
\hline $\begin{array}{l}\text { Hydrogen technology (I mean green technology) is neither a } \\
\text { mature nor a cost-effective solution for developed countries. So, I } \\
\text { think it is not a suitable solution for rural minigrids in developing } \\
\text { countries in the next immediate future. }\end{array}$ & \\
\hline $\begin{array}{l}\text { Technology not mature enough even for OECD countries, while } \\
\text { blue hydrogen is not a sustainable solution even for OECD } \\
\text { countries, blue hydrogen is suitable only when large abundancy of } \\
\text { supply, and is ment for long diatance transport of energy. } \\
\text { Situations that do not occur in rural minigrids. }\end{array}$ & $\begin{array}{l}\text {-Could become a seasonal storage for minigrids outside the } \\
\text { tropical band who experience strong resource availability seasonal } \\
\text { variations. } \\
\text {-In cases with huge abundancy of (solar) resource could become a } \\
\text { source of income for the village (a good to trade or sell). }\end{array}$ \\
\hline $\begin{array}{l}\text {-The technology is yet to be mature and research is still ongoing. } \\
\text { The cost of gettings up hydrogen based technology is high now and } \\
\text { may be like that for the decade to come. } \\
\text {-Unless strong commitment are made and more funding is given } \\
\text { for Research \& Development and large scale deveplopment to } \\
\text { drive down cost. }\end{array}$ & $\begin{array}{l}\text {-One of the key challenges in minigrids today is the storage given } \\
\text { the intermittency of renewable and high cost of batteries even } \\
\text { though is being made. } \\
\text {-In this position Hydrogen will drastically change the furture of } \\
\text { minigrids. } \\
\text { - Hydrogen could play a significant role as an altemative to store } \\
\text { excegs production from } \mathrm{RE} \text { and available when needed. }\end{array}$ \\
\hline $\begin{array}{l}\text {-If we consider the economic status of most African countries, the } \\
\text { initial investment cost would be a challenge for the Governments } \\
\text { to swiftly adopt hydrogen technologies. }\end{array}$ & Clean, reliable and Sustainable \\
\hline $\begin{array}{l}\text { Still not enough tested for rural applications, so it's hard to identify } \\
\text { its potential. }\end{array}$ & $\begin{array}{l}\text { It could be an alternative source where other resources (mainly } \\
\text { sum, wind and hydro) are scarce. }\end{array}$ \\
\hline Transportation and storage & High energy density \\
\hline
\end{tabular}

\section{Section 4: Sociodemographic}

- $\quad$ Profession: What is your current position? Options: "Student in a bachelor's degree program" (0\%), "Student in a master's degree program" (0\%), "Research associate at a university or research institute" (29\%), "Postdoc at a university or research institute" (5\%), "Professor at a university or research institute" (38\%), "Employed in the industry" (10\%), "Other" (14\%)

- $\quad$ Academic background: What is your academic background?

Options: "Economics" (24\%), "Engineering" (67\%), "Sociology" (0\%), "Natural Sciences" (5\%), "Other" (0\%)

- $\quad$ Gender: What is your gender?

Options: "female" 23.8\%, "male" 71.4\%, "other" 0\%, not stated: $4.8 \%$.

\section{- $\quad$ Age: How old are you?}

Options: "younger than 20 years old" $0 \%$, "20 to 30 years old" $28.6 \%$, "30 to 40 years old" $42.6 \%$, "40 to 50 years old" $19.0 \%$, "50 - 60 years old" $0 \%$, "60 - 70 years old" $4.76 \%$, "70 years or older" $0 \%$, not stated: $4.76 \%$.

- Which is the country, where you are currently living?

Options: See World bank list of countries.

Answers: Spain (2), Germany (4), United States (2), Algeria (1), Canada (1), Japan (1), South Africa (1), Italia (3), Benin (1), Sierra Leone (1), Malaysia (1), Not answered (3)

\section{REFERENCES}

[1] I. Arto, I. Capellan-Perez, R. Lago, G. Bueno, and R. Bermejo, "The energy requirements of a developed world," Energy Sustain Dev, vol. 33, pp. 1-13, 2016, doi: 10.1016/j.esd.2016.04.001.

[2] M. González-Eguino, "Energy poverty: An overview," Renew. Sust. Energ. Rev., vol. 47, pp. 377-385, 2015, doi: 10.1016/j.rser.2015.03.013.

[3] International Energy Agency, "Africa energy outlook 2019," 2019.

[4] World Bank. "The World Bank Data - Access to electricity (\% of rural population) - Sub-Saharan Africa." https://data.worldbank.org/indicator/ EG.ELC.ACCS.RU.ZS?locations=ZG [Feb. 17, 2021].

[5] J. Morrissey, "The energy challenge in subSaharan Africa: A guide for advocates and policy makers: Part 2: Addressing energy poverty," Oxfam Research Backgrounder, pp. 23-44, 2017.

[6] IEA, "Energy for all," International Energy Agency, Paris, 2011.

[7] D. Akinyele, E. Olabode, and A. Amole, "Review of fuel cell technologies and applications for sustainable microgrid systems," Inventions, vol. 5, no. 42, 2020, doi: 10.3390/inventions5030042.

[8] E. Topriska, M. Kolokotroni, Z. Dehouche, and E. Wilson, "Solar hydrogen system for cooking applications: Experimental and numerical study," Renew. Energy, vol. 83, pp. 717-728, 2015, Art no. Pii: S0960148115003729, doi: 10.1016/j. renene.2015.05.011.

[9] A. Tremel, P. Wasserscheid, M. Baldauf, and T. Hammer, "Techno-economic analysis for the synthesis of liquid and gaseous fuels based on hydrogen production via electrolysis," Int J Hydrogen Energ, vol. 40, pp. 11457-11464, 2018. 
[10] IRENA, "Hydrogen: A renewable energy perspective," IRENA, Abu Dhabi, 2019.

[11] M. J. Khan and M. T. Iqbal, "Pre-feasibility study of stand-alone hybrid energy systems for applications in Newfoundland," Renew. Energy, vol. 30, pp. 835-854, 2005, doi: 10.1016/j. renene.2004.09.001.

[12] L. Valverde, F. Rosa, A. del Real, A. Arce, and C. Bordons, "Modeling, simulation and experimental set-up of a renewable hydrogenbased domestic microgrid," Int J Hydrogen Energ, vol. 38, pp. 11672-11684, 2013, doi: 10.1016/j. ijhydene.2013.06.113.

[13] K. Karakoulidis, K. Mavridis, D. V. Bandekas, P. Adoniadis, C. Potolias, and N. Vordos, "Technoeconomic analysis of a stand-alone hybrid photovoltaic-dieselebattery-fuel cell power system," Renew. Energy, vol. 36, pp. 2238-2244, 2011, doi: 10.1016/j.renene.2010.12.003.

[14] S. J. Aruldoss and M. S. P. Subathra, "Renewable Energy Hybrid Powered House for Rural Electrification," Int. J. Eng. Res., vol. 2, pp. 1-7, 2013.

[15] E. Özgirgin, Y. Devrim, and B. B. Albostan, "Modeling and simulation of a hybrid photovoltaic (PV) module-electrolyzer-PEM fuel cell system for micro-cogeneration applications," Int J Hydrogen Energ, pp. 1-7, 2015.

[16] S. Rahimi, M. Meratizaman, S. Monadizadeh, and M. Amidpour, "Techno-economic analysis of wind turbine PEM (polymer electrolyte membrane) fuel cell hybrid system in standalone area," Energy, vol. 67, pp. 381-396, 2014, doi: 10.1016/j.energy.2014.01.072.

[17] S. Jemeï, D. Hissel, A. Coince, and B. AlNasrawi, "Optimization and economic analysis of an hybrid fuel cell, photovoltaic and battery electric power generation system," J. Fuel Cell Sci. Tech., vol. 3, no. 4, 2006.

[18] G. P. Giatrakos, T. D. Tsoutsos, P. M. Mouchtaropoulos, G. D. Naxakis, and G. Stavrakakis, "Sustainable energy planning based on a stand-alone hybrid renewable energy/hydrogen power system: Application in Karpathos island, Greece," Renew. Energy, vol. 34, pp. 2562-2570, 2009.

[19] Y. Kalinci, A. Hepbasli, and I. Dincer, "Technoeconomic analysis of a stand-alone hybrid renewable energy system with hydrogen production and storage options," Int J Hydrogen Energ, vol. 40, no. 24, pp. 7652-7664, 2015, doi: 10.1016/j.ijhydene.2014.10.147.

[20] R. Boudries, A. Khellafa, A. Aliane, L. Ihaddaden, and F. Khida, "PV system design for powering an industrial unit for hydrogen production," Int J Hydrogen Energ, pp. 1-8, 2014, doi: 10.1016/j. ijhydene.2014.04.166.

[21] K. Agbossou et al., "Renewable energy systems based on hydrogen for remote applications," J.
Power Sources, vol. 96, pp. 168-172, 2001.

[22] M.S. Alam and D. W. Gao, "Modeling and analysis of a wind/PV/fuel cell hybrid power system in HOMER," presented at the 2007 Second IEEE Conference on Industrial Electronics and Applications, Harbin, China, pp. 1594-1599, 2007.

[23] S. M. Hakimi and S. M. Moghaddas-Tafreshi, "Optimal sizing of a stand-alone hybrid power system via particle swarm optimization for Kahnouj area in south-east of Iran," Renew. Energy, vol. 34, pp. 1855-1862, 2009, doi: 10.1016/j.renene.2008.11.022.

[24] M. Nayeripour, M. Hoseintabar, T. Niknam, and J. Adabi, "Power management, dynamic modeling and control of wind/ FC/batterybank based hybrid power generation system for stand-alone application," Eur. T. Electr. Power, vol. 22, pp. 271-293, 2012, doi: 10.1002/etep.558.

[25] F. K. Abo-Elyousr and A. N. Nozhy, "Bi-objective economic feasibility of hybrid micro-grid systems with multiple fuel options for islanded areas in Egypt," Renew. Energy, 2018, doi: 10.1016/j.renene.2018.05.066.

[26] M. A. V. Rad, R. Ghasempour, P. Rahdan, S. Mousavi, and M. Arastounia, "Techno-economic analysis of a hybrid power system based on the cost-effective hydrogen production method for rural electrification, a case study in Iran," Energy, vol. 190, 2020, doi: 10.1016/j.energy.2019.116421.

[27] M. Jamshidi and A. Askarzadeh, "Technoeconomic analysis and size optimization of an off-grid hybrid photovoltaic, fuel cell and diesel generator system," Sustain. Cities Soc., 2018, doi: 10.1016/j.scs.2018.10.021.

[28] H. S. Das, C. W. Tan, A. H. M. Yatim, and K. Y. Lau, "Feasibility analysis of hybrid photovoltaic/battery/fuel cell energy system for an indigenous residence in East Malaysia," Renew. Sust. Energ. Rev., vol. 76, pp. 1332-1347, 2017.

[29] M. Khemariya, A. Mittalb, P. Baredarb, and A. Singh, "Cost and size optimization of solar photovoltaic and fuel cell based integrated energy system for un-electrified village," J. Energy Storage, vol. 14, pp. 62-70, 2017, doi: 10.1016/j.est.2017.09.011.

[30] B. Groenendaal. "Solar-hydrogen minigrids pioneered in Uganda." https://www. greenbuildingafrica.co.za/solar-hydrogenmini-grids-pioneered-in-uganda/ [Jan. 27, 2021].

[31] T. Chrometzka, T. Potisat, and A. Quinn. "Ditching the Diesel - Hydrogen Microgrids." Enapter. https://www.enapter.com/hydrogenmicrogrids [Jan. 27, 2021].

[32] P. Largue. "Microgrids with hydrogen fuel cells installed in rural India." Power Engineering International. https://www. powerengineeringint.com/decentralized- 
energy/microgrids-with-hydrogen-fuel-cellsinstalled-in-rural-india/ [April 16, 2021].

[33] P. Pradhan, L. Costa, D. Rybski, W. Lucht, and J. P. Kropp, "A Systematic Study of Sustainable Development Goal (SDG) Interactions," Earth's Future, pp. 1169-1179, 2017, doi: 10.1002/2017EF000632.

[34] A. Maxim, "Sustainability assessment of electricity generation technologies using weighted multi-criteria decision analysis," Energ Policy, vol. 65, pp. 284-297, 2014, Art no. Pii: S030142151300983x, doi: 10.1016/j. enpol.2013.09.059.

[35] J. J. Wang, Y. Y. Jing, C. F. Zhang, and J. H. Zhao, "Review on multi-criteria decision analysis aid in sustainable energy decision-making," Renew. Sust. Energ. Rev., vol. 13, pp. 2263-2278, 2009, doi: 10.1016/j.rser.2009.06.021.

[36] J. Wang, Y. Jing, C. Zhang, G. Shi, and X. Zhang, "A fuzzy multi-criteria decision-making model for trigeneration system," Energ Policy, vol. 36, 2008.

[37] L. Ustinovichius, E. K. Zavadskas, and V. Podvezko, "Application of a quantitative multiple criteria decision making (MCDM-1) approach to the analysis of investments in construction," Control and Cybernetics, vol. 36, pp. 251-268, 2007.

[38] RECP, euei pdf, ARE, and REN21, "Mini-grid policy toolkit: Policy and business frameworks for successful mini-grid roll-outs," Eschborn, 2014.

[39] IRENA, "Innovation outlook minigrids," 2016.

[40] IRENA, "Off-grid renewable energy systems: Status and methodological issues," 2015.

[41] H. Louie, "Off-Grid renewable energy systems in developing countries," 2018.

[42] R. Stuebi, E. Adukonu, P. Wang, T. Zhang, X. Yue, and R. Ren, "Bringing Power and Progress to Africa in a Financially and Environmentally Sustainable Manner," Boston University, Institute for Sustainable Energy, Boston, 2020.

[43] World Bank, "Technical and Economic Assessment of Off-grid, Mini-grid and Grid Electrification Technologies : Annex 1. Detailed Technology Descriptions and Cost Assumptions," Washington DC, 2007.

[44] A. Buttler, and H. Spliethoff, "Current status of water electrolysis for energy storage, grid balancing and sector coupling via power-to-gas and power-to-liquids: A review," Renew. Sust. Energ. Rev., no. 82, pp. 2440-2454, 2018, doi: 10.1016/j.rser.2017.09.003.

[45] B. Mainali, "Analyzing sustainability of energy access in developing countries," Doctoral thesis in energy technology, School of industrial engineering and management, KTH Stockholm, 2014.

[46] T. Lhendup, "Rural electrification in Bhutan and a methodology for evaluation of distributed generation system as an alternative option for rural electrification," Energy Sustain Dev, vol. 12, no. 3,2008, doi: 10.1016/S0973-0826(08)60434-2.

[47] Energy and Environment Partnership Trust Fund, "Opportunities and challenges in the mini-grid sector in Africa - Lessons learned from the EEP portfolio," 2019.

[48] D. Mentis et al., "Lighting the world: The first application of an open source, spatial electrification tool (OnSSET) on Sub-Saharan Africa," Environ. Res. Lett., vol. 12, pp.1-18, 2017.

[49] ESMAP, "Technical and Economic Assessment of Off-grid, Mini-grid and Grid Electrification Technologies," 2007.

[50] R. Boukhanouf, "Small combined heat and power (CHP) systems for commercial buildings and institutions," 2011.

[51] SHAKTI Sustainable Energy Foundation and ICF Consulting India pvt. Ltd, "Diesel Generators: Improving Efficiency and Emission Performance in India," 2017.

[52] K. R. Wheeler, "Efficient operation of diesel generator sets in remote environments," Master of Science, Virginnia Polytechnic Institut and State University, 2017.

[53] T. Smolinka et al., "Studie IndWEDe: Industrialisierung der Wasserelektrolyse in Deutschland: Chancen und Herausforderungen für nachhaltigen Wasserstoff für Verkehr, Strom und Wärme," IndWEDe, 2018.

[54] IRENA, "Measurement and estimation of offgrid solar, hydro and biogas energy," 2018.

[55] IRENA, "Prospects for the African power sector: Scenarios and strategies for Africa project," International Renewable Energy Agency, 2011.

[56] Se4all, "State of the global mini-grids market report 2020," 2020.

[57] T. E. Rasimphi, D. Tinarwo, and W. M. Gitari, "Potential of biogas technology in achieving the sustainable developmental goals: A review through case study in rural South Africa," vol. 28, pp. 1-10, doi: 10.1007/978-3-319-58538-3_401.

[58] Z. Y. Amare, "The benefits of the use of biogas energy in rural areas in Ethiopia: A case study from the Amhara National Regional State, Fogera District," AJEST, vol. 9, no. 4, pp. 332-345, 2015, doi: 10.5897/ajest2014.1838.

[59] ESMAP and World Bank Group, "Green hydrogen in developing countries," 2020.

[60] JRC, "The availability of renewable energies in a changing Africa: Assessing climate and nonclimate effects," Joint Research Centre, Brussels, 2013.

[61] R. M. Shrestha and J. S. Acharya, "Sustainable energy access planning - A framework," Asian Development Bank, 2015.

[62] G. Saur, J. Kurtz, C. Ainschough, S. Sprik, and 
M. Post, "Stationary fuel cell evaluation," NREL, 2016.

[63] African Development Bank, "Working paper 170: Development of wind energy in Africa," ADB, 2013.

[64] KTH Royal Institute of Technology, "Electrification pathways for Benin: A spatial electrification analysis based on the Open Source Spatial Electrification Tool (OnSSET)," KTH, SNV, 2018.

[65] G. Chown, N. Ash, T. Fry, and C. McNaught, "Microgrids with renewables - Lessons for Africa from international experience," 2018.

[66] World Bank, "Accelerating minigrid deployment in Sub-Saharan Africa: Lessons from Tanzania," 2016.

[67] Tim Reber, Samuel Booth, Dylan Cutler, Xiangkun Li, and J. Salasovich, "Tariff considerations for micro-grids in Sub-Saharan Africa," NREL, USAID Power Africa, 2018.

[68] A. Vagneur-Jones, "Funding the development of green hydrogen technology in the region: Introductory remarks, "Presentation at Renpower H2 SubSahara Africa"," Bloomberg NEL, 2020.

[69] International Energy Agency, "World energy outlook 2019," International Energy Agency, Paris, 2019.

[70] J. Winklmaier, S. Adli Bazan Santos, and T. Trenkle, "Economic development of rural communities in Sub-Saharan Africa through decentralized energy-water-food systems," in Intech Open, N. Edomah, Ed., 2020.

[71] A. Khellaf, "Overview of economic viability and social impact of renewable energy deployment in Africa," in Africa-EU Renewable Energy Research and Innovation Symposium 2018, 2018.

[72] A. Okunllola, O. Evbuomwan, H. Zaheer, and J. Winklmaier, "Assessment of decentralized hybrid mini-grids in Sub-Saharan Africa: Market analysis, least-cost modelling and job creation analysis," presented at the Africa-EU Renewable Energy Research and Innovation Symposium 2018, 2018.

[73] World Bank and IFC, "Hydroelectric power: A guide for developers and investors," 2018.

[74] G. P. Jenkins, and S. Baurzahn, "Off-grid solar PV: Is it an afforable or an appropriate solution for rural electrification in Sub-Saharan African countries?," Renew. Sust. Energ. Rev., vol. 60, pp. 1-33, 2014.

[75] ARE, and USAID, "Hybrid mini-grids for rural electrification: Lessons learned," 2011.

[76] USAID, and NREL, "Productive use of energy in African micro-grids: Technical and business considerations," 2018.

[77] X. C. Schmidt Rivera, E. Topriska, M. Kolokotroni, and A. Azapagic, "Environmental sustainability of renewable hydrogen in comparison with conventional cooking fuels," J. Clean. Prod., vol. 196, 2018.

[78] M. Mori, M. Jensterle, T. Mržljak, and B. Drobni?? "Life-cycle assessment of a hydrogen-based uninterruptible power supply system using renewable energy," International Journal of Life Cycle Assessment, vol. 19, pp. 1810-1822, 2014.

[79] O. Edenhofer, R. Pichs Madruga, and Y. Sokona, "Renewable energy sources and climate change mitigation special report of the intergovernmental panel on climate change," IPCC, New York, 2012.

[80] United Nations, "Clean development mechanisms small scale methodology: Renewable electricity generation for captive use and mini-grid," 2020.

[81] A. Evans, V. Strezov, and T. J. Evans, "Assessment of sustainability indicators for renewable energy technologies," Renew. Sust. Energ. Rev., vol. 13, pp. 1082-1088, 2009.

[82] M. Tiwari, "Life-cycle impacts and economic costs of small-scale renewable energy technologies in Nepal," Master of Liberal Arts in Extension Studies, Harvard University, 2018.

[83] N. Aden, A. Marty, and M. Muller, "Comparative life-cycle assessment of renewable electricity generation technologies: China 2030 scenario analysis," 2010.

[84] G. Varun, I. K. Bhat, and R. Prakash, "LCA of renewable energy for electricity generation systems - A review," Renew. Sust. Energ. Rev., vol. 13, no. 5, pp. 1067-1073, 2009, doi: https:// doi.org/10.1016/j.rser.2008.08.004.

[85] U.S. Department of Energy, "Quadrennial technology review 2015 Chapter 4: Advancing clean electric power technologies: Technology assessments," 2015.

[86] NREL, "Life-cycle greenhouse gas emissions from solar photovoltaics (fact sheet)," 2012.

[87] A. Arceo, M. Rosano, and W. K. Biswas, "Ecoefficiency analysis for remote area power supply selection in Western Australia," Clean technologies and environmental policies, vol. 20, no. 3, 2017, doi: https://doi.org/10.1007/ s10098-017-1438-6.

[88] J. Pucker, G. Jungmeier, S. Siegl, and E. M. Pötsch, "Anaerobic digestion of agricultural and other substrates--implications for greenhouse gas emissions," Animal, vol. 2, 2013, doi: 10.1017/ S1751731113000840.

[89] Y. Jin, P. Behrensa, A. Tukkera, and L. Scherer, "Water use of electricity technologies: A global meta-analysis," Renew. Sust. Energ. Rev., vol. 115, 2019, doi: https://doi.org/10.1016/j. rser.2019.109391.

[90] M. Khzouz et al., "Life cycle costing analysis: Tools and applications for determining hydrogen production cost for fuel cell vehicle technology," Energies, vol. 13, pp. 1-19, 2020, doi: 10.3390/ 
en13153783.

[91] A. Mehmeti, A. Angelis-Dimakis, S. J. McPhail, and S. Ulgiati, "Life cycle assessment and water footprint of hydrogen production methods: From conventional to emerging technologies," Environments, vol. 5, no. 24, pp. 1-19, 2018, doi: 10.3390/environments5020024.

[92] J. Meldrum, S. Nettles-Anderson, G. Heath, and J. Macknick, "Life cycle water use for electricity generation: A review and harmonization of literature estimates," Environ. Res. Lett., vol. 8, no. 1, pp. 1-19, 2013, doi: 10.1088/17489326/8/1/015031.

[93] M. Gonzalez-Sanchez, R. Seliger, F. Fahl, L. De Felice, T. Quadra, and F. Farinosi, "Freshwater use of the energy sector in Africa," Appl Energ, vol. 270, pp. 1-19, 2020, doi: 10.1016/j. apenergy.2020.115171.

[94] N. Kaza, and M. P. Curtis, "The land use energy connection," Journal of Planning Literature, vol. 29, no. 4, pp. 355-369, 2014, doi: 10.1177/0885412214542049.

[95] UNCCD, "Global land outlook: Energy and land use," UNCCD, 2017.

[96] E. G. Hertwich et al., "Integrated life-cycle assessment of electricity-supply scenarios confirms global environmental benefit of low-carbon technologies," Proceedings of the National Academy of Sciences of the United States of America, vol. 112, no. 20, pp. 6277-6282, 2015, doi: 10.1073/pnas.1312753111.

[97] D. van de Ven, I. Capellan-Peréz, and I. Arto, "The potential land requirements and related land use change emissions of solar energy.," Scientific Reports, vol. 11, 2021, doi: 10.1038/ s41598-021-82042-5.

[98] C. U. Jensen, T. E. Panduro, and T. H. Lundhede, "The vindication of Don Quixote: The impact of noise and visual pollution from wind turbines," Land economics, vol. 90, no. 4, pp. 668-684, 2014, doi: 10.3368/le.90.4.668.

[99] A. A. Patrick, and A. S. Babatope, "Examination of noise pollution from generators on the residents of Obantoko, Ogun State, Nigeria," Asian Journal of Engineering, Sciences and Technology, vol. 3, no. 1, pp. 31-41, 2013.

[100] S. Sevencan, G. A. Ciftcioglu, and N. Kadirgan, "A preliminary environmental assessment of power generation systems for a stand-alone mobile house with cradle to gate approach," Gazi University Journal of Science, vol. 24, no. 3, pp. 487-494, 2010.
[101] R. Frischknecht, "Life cycle assessment and human health impacts of electricity production," Engie Lab, 2017.

[102] UNEP, "Green energy choices: The benefits, risks and trade-offs of low-carbon technologies for electricity production," 2016.

[103] A. Fuchs, T. Demiray, and C. Evangelos, "ISCHESS - Integration of stochastic renewables in the Swiss electricity supply system," 2017.

[104] S. Oluoch, P. Lal, A. Susaeta, and N. Vedwan, "Assessment of public awareness, acceptance and attitudes towards renewable energy in Kenya.," Scientific African, vol. 9, pp. 1-13, 2020, doi: 10.1016/j.sciaf.2020.e00512.

[105] A. M. Rosso-Cerón and V. Kafarov, "Barriers to social acceptance of renewable energy systems in Colombia," Current Opinion in Chemical Engineering, vol. 10, pp. 103-110, 2015, doi: 10.1016/j.coche.2015.08.003.

[106] T. Day, M. Kurdzie, and M. Barasa, "The role of renewable energy mini-grids in Kenya's electricity sector evidence of a cost-competitive option for rural electrification and sustainable development:", New Climate Institute, 2019.

[107] M. Renner, "Rural renewable energy investments and their impact on employment," 2017.

[108] J. Rutovitz and S. Harris, "Calculating global energy sector jobs 2012 methodology," Institute for Sustainable Futures, 2012.

[109] A. Duran, and F. Sahinyasa, "An analysis of renewable mini-grid projects for rural electrification," Socio-Economic Planning Sciences, vol. 34, pp. 106739, 2020, doi: https:// doi.org/10.1016/j.seps.2020.100999.

[110] ESMAP and SE4All, "Beyond connections: Energy access redefined," 2016.

[111] E. Topriska, M. Kolokotroni, Z. Dehouche, D. T. Novieto, and E. A. Wilson, "The potential to generate solar hydrogen for cooking applications: Case studies of Ghana, Jamaica and Indonesia," Renew. Energy, vol. 95, pp. 495509, 2016, Art no. Pii: S0960148116303627, doi: 10.1016/j.renene.2016.04.060.

[112] M. Koepke and S. Groh, "Against the odds: The potential of swarm electrification for small island development states," Energy Procedia, vol. 103, pp. 363-368, 2016.

[113] D. L. McCollum et al., "Connecting the sustainable development goals by their energy inter-linkages," Environ. Res. Lett., vol. 13, no. 3, pp. 033006, 2018, doi: 10.1088/1748-9326/ aaafe3. 